\title{
Are workers more vulnerable in tradable industries?
}

\author{
Kent Eliasson $^{1,2} \cdot$ Pär Hansson ${ }^{3,4}$
}

(C) The Author(s) 2016. This article is published with open access at Springerlink.com

\begin{abstract}
Reduced trade barriers and lower costs of transportation and information have meant that a growing part of the economy has been exposed to international trade. In particular, this is the case in the service sector. We divide the service sector into a tradable and a non-tradable part using an approach to identify tradable industries utilizing a measure of regional concentration of production. We examine whether the probability of displacement is higher and income losses after displacement greater for workers in tradable services and manufacturing (tradable) than in non-tradable services. We also analyze whether the probability of re-employment is higher for workers displaced from tradable services and manufacturing than from non-tradable services. We find that in the 2000s the probability of displacement is relatively high in tradable services in comparison to non-tradable services and manufacturing. On the other hand, the probability of re-employment is higher for those displaced from tradable services. The largest income losses are found for those who had been displaced from manufacturing. Interestingly, the income losses of those displaced from manufacturing seems mainly to be due to
\end{abstract}

\footnotetext{
An earlier version of this paper was presented at the 15 th annual conference of the European Trade Study Group at the University of Birmingham, the 26th annual conference of the European Association of Labour Economists at University of Ljubljana and the 4th biennial conference of Swedish Economists at Umeå University.
}

Pär Hansson

par.hansson@oru.se

Kent Eliasson

kent.eliasson@tillvaxtanalys.se

1 Growth Analysis, Studentplan 3, 83140 Östersund, Sweden

2 Department of Economics, Umeå University, 90187 Umeå, Sweden

3 Growth Analysis, Box 574, 10131 Stockholm, Sweden

4 Örebro University School of Business, 70182 Örebro, Sweden 
longer spells of non-employment, whereas for those displaced in tradable services lower wages in their new jobs compared to their pre-displacement jobs appears to play a larger role.

Keywords Displacement costs · Re-employment · Earnings losses · Tradable services

JEL Classification $F 16 \cdot J 62 \cdot J 63$

\section{Introduction}

Manufacturing has for a long time been looked upon as a sector exposed to international trade and international trade in merchandise is considerable. In recent years, growing international trade in services, due among other things to falling costs of information and communication, is a salient feature. Some researchers, e.g. Blinder (2006), have argued that this might have painful consequences for a growing number of displaced workers in the service sector owing to the increased internationalization of services. One of the key questions in this paper is therefore to compare the displacement costs of workers in tradable services, manufacturing and, since large parts of the service sector are and will continue to be non-tradable, nontradable services.

A substantial body of literature on the costs of job displacement has emerged over the last 25 years. ${ }^{1}$ Ruhm (1991), Jacobson et al. (1993), Stevens (1997), Kletzer and Fairlie (2003), Couch and Placzek (2010), and Davis and von Wachter (2011) are examples of influential studies focusing on the United States. The literature for European countries is sparser. Important exceptions are Eliason and Storrie (2010), Hijzen et al. (2010), and Huttunen et al. (2011) who, in turn, focus on Sweden, the United Kingdom and Norway. The empirical evidence suggests substantial, often long-lasting, negative effects of displacement in terms of, for example wage and earnings losses and joblessness. The costs of job loss in manufacturing industries are particularly well studied, but some of the papers above also focus on displacement in the service sector. To our knowledge, there is no previous paper that, within a regression type framework, explicitly compares the costs of displacement in tradable and non-tradable sectors of the economy.

While data on international trade in merchandise is highly disaggregated, data on trade in services is not very detailed. ${ }^{2}$ This makes it hard to identify industries in the service sector that are exposed to international trade. To classify industries into

\footnotetext{
1 See Fallick (1996) and Kletzer (1998) for surveys of literature for the United States and OECD (2013) Annex 4A2 for a recent review of existing literature on wage and earnings effects of displacement.

2 In the official Swedish statistics, and in many other countries, international trade in services is divided into 11 categories: (i) transportation, (ii) travel, (iii) communication, (iv) construction, (v) insurance, (vi) financial service, (vii) computer and information service, (viii) royalties and license fee, (ix) other business service, (x) personal, cultural and recreational service, and (xi) government service. Moreover, the country of destination in export and the origin of imports are not available in the statistics on international trade in services.
} 
tradable and non-tradable we make use of an approach developed by Jensen and Kletzer (2006). The basic idea here is that the degree of geographical concentration of industries tells us whether the activities within an industry can be expected to be traded domestically and at least potentially to be traded internationally. Regionally concentrated industries are presumed to be tradable because the production in an industry is then localized to particular regions, whereas the consumption of the industry's output is spread out along with the distribution of incomes over the country. In our analysis we measure regional concentration of all industries in the Swedish economy by calculating locational Ginis. We assume that all industries in manufacturing are tradable and the size of the locational Ginis in manufacturing is used as a benchmark to determine whether industries in the service sector are tradable or not.

When we divide the industries in the Swedish economy into tradable and nontradable services and manufacturing we observe that over the past 20 years the employment share of non-tradable services has been close to constant, whereas the share of tradable services has grown and the share of manufacturing has declined. Actually, the way we measure tradable service the employment there has increased from being less than in manufacturing in the beginning of the studied period to being larger than in manufacturing in the end of the studied period. These shifts within the tradable sector are consistent with that service export in recent years has become more important in Sweden. ${ }^{3}$ A notable difference between tradable service and manufacturing, shown in the paper, is that tradable service is considerably more skill intensive and the heavy reduction in employment in manufacturing is driven by fewer less-skilled workers employed.

We use administrative data to identify job displacements. Job displacements are defined as job separations from an establishment that from one year to the next ceased to operate or experienced a large reduction in employment. We estimate the probability of displacement and the probability of re-employment following displacement in Sweden over the period from 2000 to 2009 and compare the probabilities in tradable services, manufacturing and non-tradable services controlling for other factors (individual, establishment and regional) that might affect displacement and re-employment.

By using administrative data we have the opportunity to follow displaced individuals before and after displacement and then contrast their development with non-displaced individuals. The most common approach to estimate earnings losses of displacement in this setting was until recently to follow Jacobson et al. (1993) and use some type of fixed-effects model. In this paper, we instead draw on Couch and Placzek (2010) and use conditional difference-in-differences matching as our main estimation strategy and compare the results from matching with those obtained using a standard fixed-effects model.

The main contribution of our paper is that we examine in which of the sectors tradable services, manufacturing or non-tradable services the earnings losses after

\footnotetext{
${ }^{3}$ For instance, while the Swedish export share of goods in world goods export has fallen, the export share of services in world service export has grown. Also, in comparison to other OECD countries the growth in service export in Sweden in the 2000s has been among the largest (Eliasson et al. 2011).
} 
displacement are largest. We also make an attempt to determine whether observed earnings losses mainly are due to lower wages in post-displacement jobs or primarily the result of periods of non-employment following displacement.

Previous closely related studies, Jensen and Kletzer (2006, 2008), are based on the Displaced Worker Survey (DWS). The DWS is a survey of a cross-section of individuals who have been involuntary displaced during a preceding three-year period and that is nationally representative of the United States. Jensen and Kletzer (2006) report the incidence, scope and characteristics of job displacement in manufacturing, tradable non-manufacturing and not tradable non-manufacturing from 2001 to 2003, while their 2008 paper is an update for 2003-2005. Jensen and Kletzer present their results as summary statistics for the different sectors, i.e. their analysis is not carried out, as in the present study, within a regression framework. This is important because, as will stand out clearly in the paper, there are considerable variations among the studied sectors in the characteristics of workers, establishments and locations. Another advantage with our study is that we can follow displaced workers for several years before and after displacement as well as compare their development with non-displaced individuals. In the paper we relate our findings for Sweden to Jensen and Kletzer's results for the United States.

Two recent related studies, Autor et al. (2014) and Hummels et al. (2014), use detailed data on individual level to analyze the effect of increased goods import on earnings and employment in manufacturing industries. Autor et al. (2014) examine how exposure of import competition from China has affected the earnings and employment of US workers in manufacturing from 1992 to 2007. They find that there are significant worker-level adjustments to import shocks, e.g. in terms of lower cumulative earnings, and that the shocks had hit workers unevenly; for instance, individuals with low initial wage levels are more severely affected. The other study by Hummels et al. (2014) is based on matched Danish worker-firm data between 1995 and 2006 and they examine the effects on wages of offshoring, i.e. increased imports on firm level of products similar to the goods sold by the firm. Hummels et al. (2014) obtain comparable results from offshoring to that Autor et al. (2014) get from the surge of imports from China, i.e. low-skilled (low-wage) workers are harder hit.

A similarity between the two studies is that they carry out analyses on cohorts of workers employed in firms (industries) prior to an offshoring shock (China's emergence on the world market) and track cohort members over time. The cohort approach includes all individuals in a firm (industry) that are affected by a globalization shock and not just the displaced and consequently does not condition on job separation. By that it is possible to avoid selection problems due to that displaced individuals most likely are not randomly selected. ${ }^{4}$ An advantage is thus that it captures not just earnings losses associated with job loss but also other types of adjustment costs. That could be changes in earnings at the initial employer or changes in earnings associated with moving between employers or industries.

\footnotetext{
${ }^{4}$ For further discussion about potential selection bias due to non-random selection of displaced workers, see Sect. 2.3.
} 
Another advantage with the studies by Hummels et al. (2014) and Autor et al. (2014) is that they take into account heterogeneities between firms within industries or between industries within sectors; shocks from the increased globalization, in terms of increased offshoring, import competition and exports, hit firms within an industry (in various industries) differently. However, for our purposes a cohort approach is not useful because it has to be connected with a trade shock that can be measured using trade data.

In contrast to the two studies above focusing on manufacturing and the effects of international trade in goods our aim is to analyze the impact of exposure to international trade in services, as well as to international trade in goods. Estimating how changes in import intensities on industry- or firm-level affects earnings and employment, as in the studies above, is due to lack of data on international trade in services on disaggregated level not a worthwhile strategy. Notice also that instead of a cohort-based analysis we examine displacement costs and not only in manufacturing but also in tradable and non-tradable services. Accordingly, a contribution of our study is that we are able to say something about displacement costs in a sector of growing importance that most other similar studies are silent about, namely tradable services. The division into three sectors is admittedly crude, yet we find significant differences in displacement costs among them, and moreover, the reasons behind the displacement costs appear to vary between the sectors.

Reasonably, trade exposure increases job churning and the cost of displacement (unemployment and lower wages) is higher in a contracting sector (manufacturing) than in an expanding (tradable services). To preview the results in the paper, our findings are that the probability of displacement is higher in sectors exposed to international trade. However, the prospects for re-employment seem to be brighter for displaced workers in tradable services than in manufacturing. In line with this we also find that the income losses are largest for displaced workers in manufacturing. However, it seems that while the main reason behind the earnings losses of those displaced in manufacturing is difficulties to find new jobs after displacement, lower wages in the new positions than in pre-displacement positions is a factor of greater importance for the earnings losses of those displaced in tradable services.

The plan of the paper is as follows. Section 2 defines important concepts, describes the data sample, and provides some descriptive statistics. In Sect. 3, we study displacement risks and re-employment opportunities. Section 4 contains the econometric analysis of the effects of displacement on earnings. Finally, Sect. 5 summarizes and concludes.

\section{Sectors, trade in services and displacement}

\subsection{Manufacturing, tradable and non-tradable services}

First we have to identify the industries in the tradable service sector. To this end we utilize an approach suggested by Jensen and Kletzer (2006). By measuring the regional concentration of different industries we determine which industries are tradable and non-tradable. We measure regional concentration by calculating 
locational Ginis for various industries in the Swedish economy in $2005 .^{5}$ Figure 1 presents box plots of the Gini coefficients.

Based on these locational Ginis we classify industries according to where trade seems to occur regionally and where no regional trade appears to exist. It is well known that the industries in manufacturing industries are more or less exposed to international competition and that international trade in goods takes place on a large scale. Therefore, we use the size of the locational Ginis in manufacturing industries as a benchmark to identify industries in the service sector where international trade might exist. We establish the cut-off point between tradable and non-tradable industries, admittedly somewhat arbitrarily, as Ginis at $0.20{ }^{6}$ Thus this implies that all 'Manufacturing' and 'Mining' industries are categorized as tradable but also many industries in 'Financial intermediation', 'Transport and Communication' and 'Business Services', whereas the majority of industries within the sectors 'Construction', 'Education' (except higher education) and 'Wholesale and Retail Trade ${ }^{7}$ are defined as non-tradables. One outstanding feature is that many of the dominating industries in tradable services are business, professional and technical service activities of different kinds. ${ }^{8}$

Another check whether regional concentration is a reasonable indicator on international tradability is to examine the relationship between locational Ginis and trade intensities ([export + import]/production value) on industry level in manufacturing. There is a positive relation between Ginis and trade intensities in Swedish manufacturing industries, which is significant at the $10 \%$ level. ${ }^{9}$ The positive relationship might have been even stronger if there are no trade barriers in manufacturing industries.

\footnotetext{
${ }^{5}$ Industries are primarily defined on three-digit NACE (Classification of Economic Activities in the European Community) level (172 industries), and as our geographic entity, we use a definition of functional labor market (FA) regions (72 regions).The FA regions are preferred to traditional administrative units such as municipalities or counties. The FA regions constitute integrated housing and labor market areas where most people can find both a place to live and a place to work. By their construction, they are defined to maximize internal commuting possibilities and minimize commuting flows across the regional borders. A complete list of the locational Ginis and employment in industries on three-digit level in 2005 is given in Appendix Table 6.

6 There is one exception. The industry 752 'Provision of services to the community as a whole' with a Gini at 0.235 , which consists of 'Foreign affairs', 'Defense', 'Justice and judicial activities', 'Public security' and 'Fire service' and large employment (78,097 in 2010), has been moved from tradable services to non-tradable services. In Eliasson et al. (2012a) we present (in Tables 2, 3, 4), as form of sensitivity analysis, some result on how the tradable and non-tradable sectors are affected when we increase the cut-off from 0.2 to 0.3 . Obviously, the size of the tradable sectors decreases but otherwise more or less the same patterns remain, e.g. for the share of skilled labor and average earnings within sectors.

${ }^{7}$ Since retailing in most cases require presence (shops) close to the consumers it is plausible to classify retail trade as nontradable service and by using our definition these industries are in most cases nontradable (see Table 6 in Appendix). Interestingly, an exception is the industry 526 'Retail sale not in stores', where the Gini is 0.45 , and accordingly classified as tradable.

${ }^{8}$ The three largest industries in tradable services in terms of employment in 2010 are: 741 'Legal and financial consulting' $(94,665), 722$ 'Software consultancy' $(90,546)$ and 742 'Architectural, engineering and technical consulting' $(77,553)$.

${ }^{9}$ Formally, $T I_{i}=0.46+0.95 G_{i}$, where $T I_{i}$ is trade intensity and $G_{i}$ is Gini in industry $i$; the $t$-value for the coefficient on $G_{i}$ is 1.85 . Trade intensities and Ginis are for 2005 .
} 


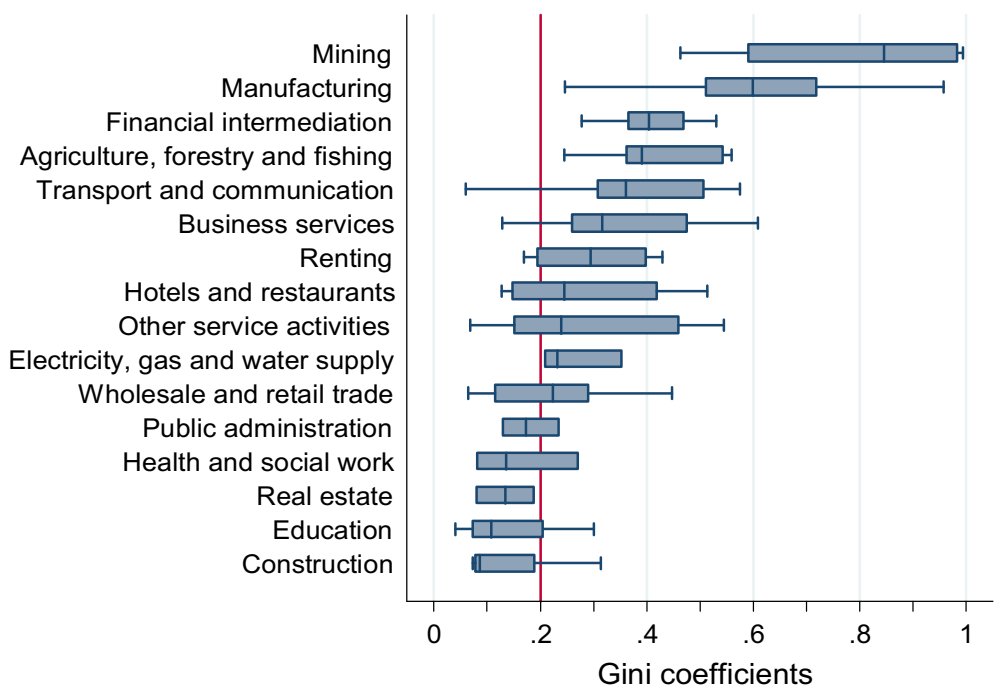

Fig. 1 Regional concentration of different industries 2005. Remark The box plots illustrate the distribution of industries included in each sector respectively, e.g. Manufacturing. The distributions are summarized by the median, lower and upper quartile, minimum and maximum. The vertical line (Gini $=0.2)$ is the cut-off that determine which industries that are tradable or non-tradable. Source: Statistics Sweden, Register-based labor market statistics (RAMS)

In our analysis we divide the economy into three broad sectors, manufacturing, tradable and non-tradable services, and Fig. 2 shows how employment in those sectors has developed from 1990 to $2010 .^{10}$

It can be seen that, while the non-tradable service sector has remained almost constant between 1990 and 2010, the tradable service sector, from having a smaller share than manufacturing in 1990, has grown and the manufacturing sector has contracted. This shift within the tradable part of the Swedish economy from manufacturing to tradable services is an indication of the increased importance of the tradable service sector in recent years.

In Table 1, we separate the employment into skilled and less-skilled labor, where skilled labor is employees with some post-secondary education. The pattern of the employment changes differs very much between the sectors. In manufacturing the employment of skilled labor has increased considerably, whereas the employment of less-skilled labor has decreased substantially. In tradable services the employment of skilled labor has grown considerably, whereas the employment of less-skilled labor has been more or less unchanged. Finally, in non-tradable services the employment of skilled labor has increased (in percentage points not as much as in tradable services) and the employment of lessskilled labor has fallen (in percentage points less than in manufacturing).

Another striking feature is that the three studied sectors also differ regarding the share of skilled labor in the sector. Table 1 shows that the skill intensity is

${ }^{10}$ We use a residual approach to define the service sector. This means that all activities not included in the primary sector, NACE 01-14, and in the secondary (manufacturing) sector, NACE 15-37, are classified as services. 


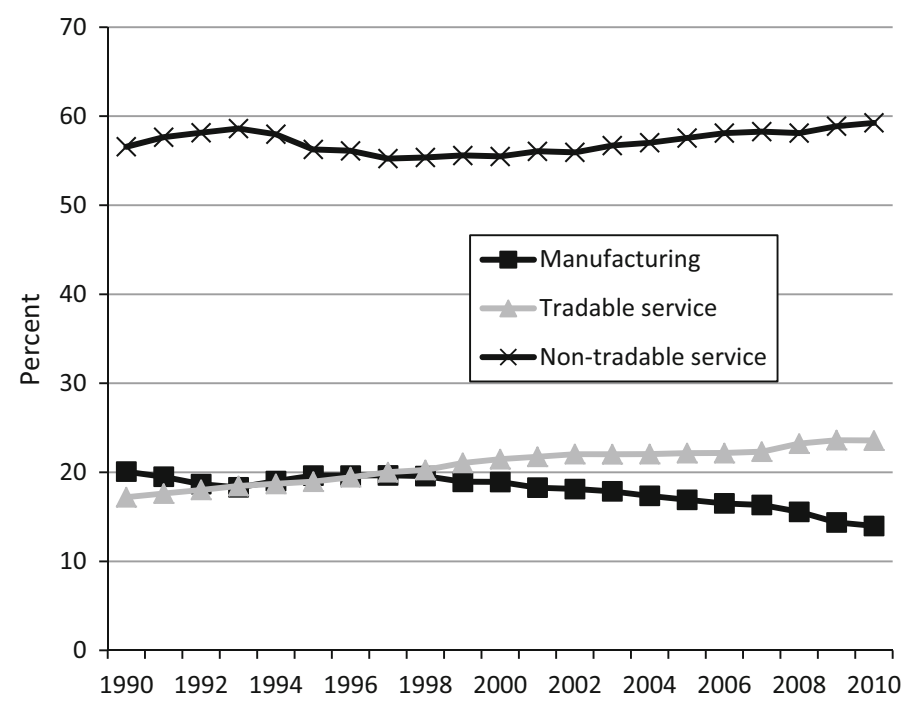

Fig. 2 Employment shares of manufacturing, tradable and non-tradable services 1990-2010. Source: Statistics Sweden, Register-based labor market statistics (RAMS)

Table 1 Employment of skilled and less-skilled labor in manufacturing, tradable and non-tradable services 1990-2010

\begin{tabular}{|c|c|c|c|c|c|c|c|c|c|}
\hline \multirow[t]{2}{*}{ Year } & \multicolumn{3}{|c|}{ Manufacturing } & \multicolumn{3}{|c|}{ Tradable services } & \multicolumn{3}{|c|}{ Non-tradable services } \\
\hline & Skilled & $\begin{array}{l}\text { Less- } \\
\text { skilled }\end{array}$ & $\begin{array}{l}\text { Skill } \\
\text { share }\end{array}$ & Skilled & $\begin{array}{l}\text { Less- } \\
\text { skilled }\end{array}$ & $\begin{array}{l}\text { Skill } \\
\text { share }\end{array}$ & Skilled & $\begin{array}{l}\text { Less- } \\
\text { skilled }\end{array}$ & $\begin{array}{l}\text { Skill } \\
\text { share }\end{array}$ \\
\hline 1990 & 112 & 786 & 12.5 & 247 & 522 & 32.1 & 593 & 1938 & 23.4 \\
\hline 2010 & 168 & 447 & 27.4 & 531 & 507 & 51.2 & 961 & 1648 & 36.8 \\
\hline$\Delta$ & 56 & -339 & 14.9 & 284 & -15 & 19.1 & 368 & -290 & 13.4 \\
\hline$\%$ & 50.2 & -43.2 & & 115.0 & -3.0 & & 62.1 & -15.0 & \\
\hline
\end{tabular}

Source: Statistics Sweden, Register-based labor market statistics (RAMS)

Employment figures are in thousands

considerably higher in tradable services than in manufacturing and in non-tradable services. In 2010, around half of the people employed in tradable services had some form of post-secondary education. Moreover, the largest increase in skill intensity is in tradable services (19\% points), whereas the smallest rate of increase can be found in non-tradable services (13\% points). ${ }^{11}$ In other words, it seems that the share of skilled labor has grown faster in sectors exposed to international trade. ${ }^{12} \mathrm{~A}$

\footnotetext{
11 Yet the slowest rate of increase in skilled labor is in manufacturing, but since the reduction in lessskilled is larger in manufacturing than in non-tradable services, the increase in skill intensity is larger in manufacturing (15\% points) than in non-tradable services.

12 The proportion of skilled labor in the tradable service sector has increased by $19 \%$ points, in the manufacturing industry by $15 \%$ points and in the non-tradable service sector by $13 \%$ points.
} 
plausible interpretation of this is that it is first and foremost in this part of the economy that the trend towards less-skilled jobs disappearing (manufacturing) at the same time as more skilled jobs are created (tradable services) has been particularly strong.

\subsection{Swedish trade in services}

Before we begin to analyze displacement risks and re-employment opportunities in different sectors we provide some facts about services trade in Sweden. ${ }^{13}$ At first we notice that, although the goods production is substantially lower than the service production, the trade in goods is larger than the trade in services. The latter is evident from Fig. 3, which shows exports and imports of goods and services in Sweden from 1993 to 2014, and where the graphs of the goods trade lie clearly above the graphs of the services trade. The Swedish trade in services has grown continuously over the period, whereas the trade in goods in the last years has leveled off. During the period Sweden is a net exporter of goods and in the mid-2000s Sweden become net exporter of services too. In 2014, the export of services is $28 \%$ of the total exports of goods and services. This is an increase over the period, since the corresponding share in 1993 is $25 \%$, and indicates that the services exports in Sweden has grown faster than the goods exports. For the imports the increase is smaller; the import share of services of total imports rose from $28 \% 1993$ to $29 \%$ 2014. Finally, we observe in Fig. 3 that the economic crisis in 2009 affected the Swedish trade in services much less than the trade in goods.

One explanation why there is less international trade in services than in goods is that physical presence, often due to non-storability, is required for service delivery, and producers and consumers are then likely to be located in the same place at the same time. Another is that remaining barriers to trade are larger and regulations more extensive for services than for goods. Also, there are reasons to believe that the importance of services exports relative to goods exports is underestimated. The input of imported intermediates is larger in the exports of goods than in the exports of services. Moreover, the service content in the exports of goods is much larger than the goods content in the services exports. ${ }^{14}$

In Sweden and in other OECD countries the trade statistics on services is divided into 11 categories. To give an idea about these categories relative importance and how services exports has developed in those groups in Sweden, Table 2 presents exports shares of total services exports in Sweden and OECD in 2010 and average annual export growth in Sweden compared to in OECD as a whole between 2000 and 2010 in various service categories.

In Table 2 we can see that the services export has grown faster in Sweden than in OECD; the annual average export growth in the 2000s has been $19 \%$ and in OECD $13 \%$. The service categories with the largest export shares in Sweden, as well as in

\footnotetext{
13 There is a growing literature on service trade and Francois and Hoekman (2010) is a survey of recent works. Lately, there has been a strand of articles examining trading firms in the service sector and service traders, e.g. Breinlich and Criscuolo (2011), Haller et al. (2014) and Malchow-Møller et al. (2015). A more detailed presentation of the Swedish trade in services is given by Eliasson et al. (2011).

14 Eliasson et al. (2011) figures 2 and 3.
} 


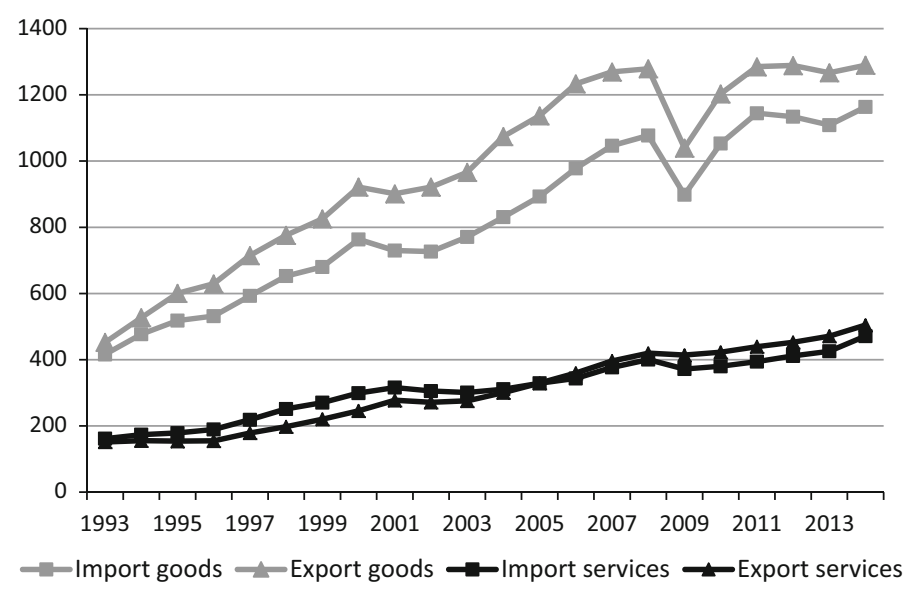

Fig. 3 Services and goods trade in Sweden 1993-2014, 2000 constant prices, billions SEK. Source: Statistics Sweden, National Accounts

Table 2 Exports shares of total services export 2010 and average annual growth of exports 2000-2010 in Sweden and OECD for various service categories

\begin{tabular}{|c|c|c|c|c|}
\hline \multirow[t]{3}{*}{ Service category } & \multicolumn{2}{|c|}{ Export share } & \multicolumn{2}{|c|}{ Export growth } \\
\hline & \multicolumn{2}{|l|}{2010} & \multicolumn{2}{|c|}{ 2000-2010 } \\
\hline & Sweden & OECD & Sweden & OECD \\
\hline Transportation & 16.7 & 20.2 & 10.6 & 10.3 \\
\hline Travel & 14.2 & 20.8 & 11.3 & 5.8 \\
\hline Communication & 3.0 & 2.5 & 18.3 & 18.5 \\
\hline Construction & 1.4 & 2.5 & 2.2 & 16.3 \\
\hline Insurance & 1.3 & 3.1 & 5.5 & 26.5 \\
\hline Financial & 1.7 & 8.6 & 4.9 & 17.2 \\
\hline Computer and information & 11.7 & 5.2 & 49.8 & 31.0 \\
\hline Royalties and license & 9.4 & 9.2 & 35.1 & 18.2 \\
\hline Other business services & 39.0 & 25.4 & 23.1 & 17.6 \\
\hline Personal, cultural and recreational & 0.6 & 0.9 & 23.4 & 7.3 \\
\hline Government services & 0.9 & 1.6 & 12.2 & 10.1 \\
\hline Total & 100 & 100 & 18.6 & 12.7 \\
\hline
\end{tabular}

Source: OECD, Statistics on International Trade in Services: Volume I: Detailed Tables by Service Categories

OECD, are 'Other business services', 'Travel' and 'Transportation'. While the export growth in Sweden in the latter two categories has been relatively modest, it has been high in 'Other business services'. Other categories with high export growth in Sweden are 'Computer and information' and Royalties and license'. High export growth in 'Computer and information' and 'Other business services' is consistent 
with high employment growth in important tradable service industries, such as 722 'Software consultancy' or 742 'Architectural, engineering and technical consultancy'.

\subsection{Definitions of displacement and sample restrictions}

By job displacement we have in mind here involuntary job separations due to exogenous shocks such as results from structural changes. This means that we would wish that we could distinguish such job separation from other forms of job separation like voluntary quits. However, in practice that might be difficult.

To identify job displacement we use linked employer-employee data based on administrative registers kept by Statistics Sweden. The definition of displacement is based on the unit of establishments ${ }^{15}$ and we use a procedure common in the recent literature. ${ }^{16}$ Displaced workers are defined as workers separated from an establishment between year $t-1$ and year $t$ and the establishment in question has: (i) experienced an absolute reduction in employment of 5 employees or more and a relative reduction in employment of at least $30 \%$ between $t-1$ and $t$ (mass dismissal), ${ }^{17}$ or (ii) closed down between $t-1$ and $t$ (establishment closure). ${ }^{18}$ In the analyses to follow, the two events are combined into a single category of displacement and attributed to year $t$.

With such a definition of displacement there are potential selection problems. Workers who remain until year $t-1$ are not necessarily a random sample of all workers affected by a mass dismissal or establishment closure. It might be the case that workers with relatively better outside opportunities realize that the establishment in which they are employed has run into problems and decide to leave before year $t-1$, so called early-leavers. But early-leavers might also be workers who are less valuable to a downsizing establishment and whom the employer therefore chose to lay off first. In the former case early-leavers are a positively selected sample of all workers affected by the displacement event and in the latter case a negatively selected sample. There are a few papers in the displacement literature that employ a time window around the displacement event that include both early-leavers and

\footnotetext{
15 The reason for carrying out the analysis of displacement on the unit of establishments instead of firms is that the identity number of the firm is less stable, i.e. more of a variable than a time consistent identifier. The firm is more or less free to change identity number over time and this is commonly done in connection with changes in ownership or restructuring events such as acquisitions, splits or mergers. Statistics Sweden makes no real effort to construct time consistent identity numbers for firms. For establishments, on the other hand, they do invest considerable resources in constructing time consistent identity numbers, in particular for establishments with 10 or more employees. This means that using the firm's identity number will most likely lead to considerable overestimation of true displacement rates due to false firm deaths.

16 E.g. Hijzen et al. (2010) and Huttunen et al. (2011).

17 To some degree this is an arbitrary definition, but has often been justified as being consistent with the definition in the seminal article by Jacobson et al. (1993).

18 If a worker is separated from an establishment according to the stated criteria but in year $t$ is found to be employed in another establishment within the same firm, he/she will not be classified as displaced. This type of within-firm mobility of workers is most likely to be associated with organizational restructuring and not a consequence of real displacements. Not imposing this restriction would therefore risk introducing an upward bias in the number of true displacements.
} 
stayers and compare the effect of displacement for the two groups. The empirical results are ambiguous. ${ }^{19}$

We have placed several restrictions on the samples used in the analysis. To avoid quick job separations, for instance, owing to poor job matching or short temporary contracts we include only workers with at least one year of tenure with the same employer. ${ }^{20}$ We exclude those who work in the primary sector (agriculture, forestry and mining) as well as in public administration, defense, for private households or international organizations. Those who hold more than one job prior to displacement are also omitted. We also leave out employers, self-employed and unpaid family workers. The analysis covers workers from establishments with 10 employees or more in the year before displacement. Finally, we examine only workers aged 20-64 years the year prior to displacement. We eliminate young workers for the same reason as workers with short tenure. Older workers are omitted because for them it may be difficult to differentiate between displacement and retirement.

\subsection{Displacement rates and characteristics of displaced workers}

To give a long-term view of displacement in Sweden, in Fig. 4 we show the risk of displacement in Sweden between 1990 and 2009. Displacement rates are expressed as the number of employees aged 20-64 who are displaced from one year to next as a proportion of all employees aged 20-64.

With the exception of the crisis years of 1992/93 displacement rates have varied between 1.8 and $3.1 \%$. The average for the 1994-2009 period is $2.4 \%$ and the highest rates for that period appear in the years around the turn of the millennium. We observe an increase in the displacement rate during the 2008/2009 crises that nevertheless is not exceptionally high.

In Fig. 5 we look at the displacement rates in manufacturing, tradable and nontradable services between 2000 and 2009 and we can see that the rates were higher in the tradable sector, particularly in tradable services. The gap in displacement rates between tradable services and manufacturing is largest at the beginning of the period (when the dot.com bubble burst), while they are practically the same during the 2008/2009 crisis. This indicates that manufacturing was harder hit by that crisis than tradable services. A major contributory factor is most likely, as can be seen in

\footnotetext{
19 Eliason and Storrie (2006) focus on establishment closures in Sweden and find larger negative effects of displacement on earnings in a sample including both early-leavers and stayers compared to a sample excluding early-leavers. One possible explanation for this result is that early-levers are a negatively selected sample (e.g. those whom the employer chose to lay off first). Carneiro and Portugal (2006) study firm closures in Portugal and conclude that the earnings losses of early-leavers does not differ substantially from the earnings losses of workers who remain in the firm until the closing event. Schwerdt (2011) focus on establishment closures in Austria and find that the cost of job loss is significantly lower for early-leavers compared to ultimately displaced stayers. This result indicates that early-leavers are a positively selected group with good outside options.

20 Jacobson et al. (1993) and Couch and Placzek (2010) are two examples of studies that focus on displacement of long-tenured workers (six or more years of tenure). But there are many studies that also include workers with shorter tenure. For instance, Eliason and Storrie (2006) and Schwerdt (2011) focus on job losses among workers with at least one year of tenure.
} 


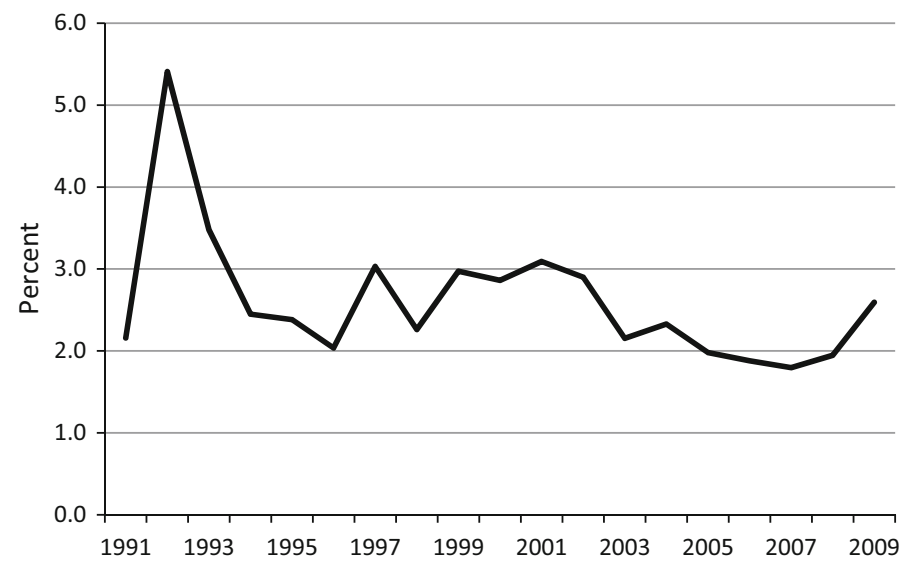

Fig. 4 Displacement rates in Sweden 1990-2009. Source: Statistics Sweden, Register-based labor market statistics (RAMS)

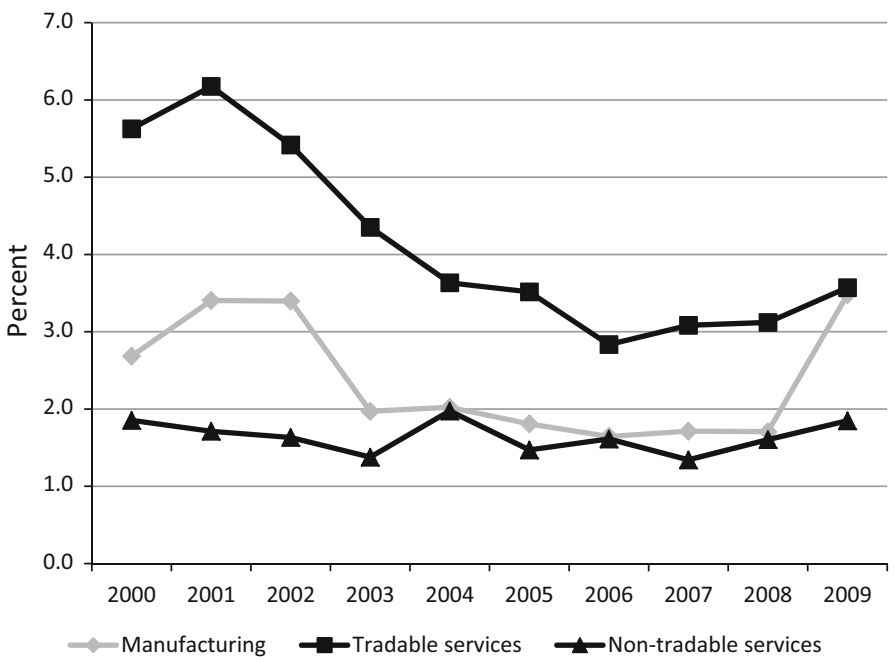

Fig. 5 Displacement rates by sectors 2000-2009. Source: Statistics Sweden, Register-based labor market statistics (RAMS)

Fig. 3, that the export of goods heavily deteriorated in 2009 (almost $17 \%$ ) while the export of services remained nearly constant (decreased with slightly more than $1 \%$ ).

If we compare the pattern in Fig. 5 with the descriptive results in Jensen and Kletzer (2006) for the years 2001-2003 there are some similarities. ${ }^{21}$ Firstly, there

21 The displacement rates in the United States are based on self-reported data from the Displaced Worker Survey (DWS). Therefore, a direct comparison of absolute levels of displacement rates in different sectors in Sweden (register data) and the United States (self-reported data) is not advisable. 
is a big difference in displacement rates between tradable and non-tradable services, where non-tradable services have lower displacement rates. Secondly, displacement rates in tradable services are high both in Sweden and in the United States at the beginning of the 2000s. However, a notable difference between Sweden and the United States at that time is that in the United States the displacement rate in manufacturing is higher than the displacement rate in tradable services.

To examine whether there are any differences between displaced workers in manufacturing, tradable and non-tradable services, in Table 3 we present characteristics of displaced workers in these sectors in 2009. One of the most striking features is that the displaced workers in tradable services have a much higher level of education than in manufacturing; $48 \%$ of the displaced in tradable services have a post-secondary education while the corresponding share for manufacturing is $18 \%$. Other interesting facts are that in tradable services, in comparison to manufacturing, the displaced have to a larger extent been working in smaller establishments, and regionally the displaced in tradable services are more concentrated to larger cities than manufacturing. Finally, the proportion of male workers is larger among the displaced, both in tradable service and in manufacturing, but less likely to be male in tradable services.

\section{Displacement risks and re-employment opportunities}

Not surprisingly, we found in the previous section that the displacement rates seem to be higher in the tradable sectors, and in particular in tradable services. Given that the employment in tradable services has increased, whereas the employment in manufacturing has decreased, we would expect the chances for those displaced from tradable service to be better to find a new job than for those displaced from manufacturing. The descriptive statistics in Table 3 also indicated some interesting differences in pre-displacement characteristics for workers displaced from the various sectors.

In this section we continue with an econometric analysis of displacement risks as well as re-employment probabilities. By using a regression framework to condition on a number of individual, establishment and regional variables, we will be able to more carefully study whether there are any differences in displacement risks and reemployment prospects for workers employed in the sectors in question.

The analysis of displacement and re-employment is based on data for 2000-2009. For each year $t$, we have a population of about 1.9-2.2 million workers fulfilling the basic sample restrictions described in Sect. 2.2. From each of these years we have drawn a $10 \%$ random sample of individuals and then stacked these observations together, giving us a pooled sample with approximately 2.1 million individuals. This is the data set used for the probability of displacement analysis. Following the previously described definition of displacement, the sample includes roughly 49,000 individuals $(2.3 \%)$ that between year $t-1$ and year $t$ were displaced, either through establishment closure or mass dismissal. The sample of 49,000 displaced workers is then used in the likelihood of re-employment analysis. Approximately 
Table 3 Proportions of displaced workers by worker and establishment characteristics in different sectors, 2009

\begin{tabular}{|c|c|c|c|}
\hline & Manufacturing & Tradable services & Non-tradable services \\
\hline \multicolumn{4}{|l|}{ Gender } \\
\hline Men & 0.76 & 0.62 & 0.60 \\
\hline Women & 0.24 & 0.38 & 0.40 \\
\hline \multicolumn{4}{|l|}{ Age } \\
\hline $20-24$ & 0.13 & 0.07 & 0.15 \\
\hline $25-34$ & 0.26 & 0.29 & 0.26 \\
\hline $35-44$ & 0.28 & 0.32 & 0.24 \\
\hline $45-54$ & 0.20 & 0.19 & 0.19 \\
\hline $55-44$ & 0.13 & 0.13 & 0.15 \\
\hline \multicolumn{4}{|l|}{ Level of education } \\
\hline Less than secondary (ISCED 0-2) & 0.17 & 0.07 & 0.14 \\
\hline Secondary (ISCED 3) & 0.65 & 0.45 & 0.60 \\
\hline Post-secondary (ISCED 4-6) & 0.18 & 0.48 & 0.25 \\
\hline Level of education unavailable & 0.00 & 0.00 & 0.01 \\
\hline \multicolumn{4}{|l|}{ Establishment size } \\
\hline $10-49$ & 0.35 & 0.50 & 0.60 \\
\hline 50-99 & 0.19 & 0.16 & 0.20 \\
\hline 100-199 & 0.15 & 0.13 & 0.11 \\
\hline $200-499$ & 0.16 & 0.18 & 0.06 \\
\hline $500+$ & 0.15 & 0.02 & 0.03 \\
\hline \multicolumn{4}{|l|}{ Sector in previous job } \\
\hline Private & 0.99 & 0.94 & 0.73 \\
\hline Public & 0.01 & 0.06 & 0.27 \\
\hline \multicolumn{4}{|l|}{ Region of residence } \\
\hline STOCKHOLM (SE11) & 0.06 & 0.39 & 0.27 \\
\hline ÖSTRA MELLANSVERIGE (SE12) & 0.16 & 0.13 & 0.16 \\
\hline SMÅLAND MED ÖARNA (SE21) & 0.16 & 0.05 & 0.06 \\
\hline SYDSVERIGE (SE22) & 0.11 & 0.13 & 0.14 \\
\hline VÄSTSVERIGE (SE23) & 0.27 & 0.17 & 0.22 \\
\hline NORRA MELLANSVERIGE (SE31) & 0.12 & 0.05 & 0.08 \\
\hline MELLERSTA NORRLAND (SE32) & 0.04 & 0.05 & 0.04 \\
\hline ÖVRE NORRLAND (SE33) & 0.07 & 0.03 & 0.04 \\
\hline
\end{tabular}

All variables refer to year $t-1$

43,000 (88\%) of the individuals displaced between year $t-1$ and year $t$ were reemployed by another establishment in year $t$.

Both the displacement and the re-employment analyses are based on probit regression models. In the former case, the dependent variable is coded as 1 if an individual was displaced between year $t-1$ and year $t$, and 0 otherwise. In the latter case, the dependent variable is coded as 1 if a worker displaced between year 
$t-1$ and year $t$ was re-employed by another establishment in year $t$, and 0 otherwise. The specification of the probit models includes a number of individual, establishment and regional characteristics as explanatory variables. ${ }^{22}$ All explanatory variables refer to year $t-1$.

Table 4 presents estimates of the displacement and re-employment probit models. The first two rows report the effect of being employed in the manufacturing or tradable service sector compared to the reference category, which is the nontradable service sector. Workers employed in tradable services clearly face the highest risk of job loss but, on the other hand, are most likely to be re-employed after displacement. ${ }^{23}$ Workers employed in manufacturing confront the unfortunate combination of a comparatively high risk of displacement and the lowest chance of re-employment. This suggests relatively high costs of displacement for workers employed in manufacturing.

Turning to the individual characteristics of workers, ${ }^{24}$ we see a non-linear effect of age on displacement and re-employment. The probability of displacement decreases with age at an increasing rate, whereas the likelihood of re-employment rises with age at a decreasing rate. The results indicate clear differences between men and women. Men are more likely to be displaced but, on the other hand, are more likely to be reemployed after job loss. We further find familiar educational attainment differences. ${ }^{25}$ Workers with less than secondary or secondary education experience a higher risk of job loss than workers with post-secondary education (reference category). In terms of re-employment, the results clearly show that the likelihood of finding a new job after displacement is smaller the lower the level of education. This indicates relatively high costs of displacement for less educated workers.

Turning to the establishment characteristics, we find that workers employed in the private sector face a higher risk of job loss than workers employed in the public sector but, on the other hand, private sector workers are more likely to be reemployed after displacement. We also find that the probability of displacement decreases with the size of the establishment in terms of employment and, further, that the likelihood of re-employment in the event of job loss increases with establishment size (10-49 employees serves as reference category). This suggests relatively high displacement costs for workers employed at small establishment.

Finally, the results indicate some differences depending on region of residence, where we have used the Swedish NUTS 2 level as regional classification. The risk of displacement is higher for workers residing in the Stockholm region (reference category) than in any of the other seven included regions. The geographical pattern

\footnotetext{
22 The included variables are standard covariates commonly appearing in previous empirical literature on job displacement. One important characteristic that we unfortunately lack information about is job tenure. It is a stylized fact in the job displacement literature that workers with short tenure face a higher risk of job loss.

23 Also in the United States in the beginning of the 2000s the re-employment rate is higher in tradable services than in manufacturing and non-tradable services (Jensen and Kletzer 2006, 2008).

24 For the individual and establishment characteristics discussed below we get similar results as in many other OECD countries (OECD 2013 pp. 197-202).

25 See e.g. Borland et al. (2002).
} 
Table 4 Probit estimates of displacement and reemployment

The model specifications also include time dummies that control for year-specific effects. **, * Significance at the 1 and $5 \%$ level respectively

\begin{tabular}{|c|c|c|c|c|}
\hline & \multicolumn{2}{|c|}{ Displacement } & \multicolumn{2}{|c|}{ Re-employment } \\
\hline & Coefficient & SE & Coefficient & SE \\
\hline \multicolumn{5}{|l|}{ Sector } \\
\hline Manufacturing & $0.0772 * *$ & 0.0061 & $-0.1153 * *$ & 0.0213 \\
\hline Tradable services & $0.2445 * *$ & 0.0052 & $0.1052 * *$ & 0.0194 \\
\hline \multicolumn{5}{|c|}{ Individual characteristics } \\
\hline Age & $-0.0161 * *$ & 0.0013 & $0.1443 * *$ & 0.0047 \\
\hline Age squared & $0.0001 * *$ & 0.0000 & $-0.0018^{* *}$ & 0.0001 \\
\hline Male & $0.0821 * *$ & 0.0043 & $0.2466^{* *}$ & 0.0161 \\
\hline Less than secondary & $0.0137^{*}$ & 0.0066 & $-0.2663^{* *}$ & 0.0247 \\
\hline Secondary & $0.0114 *$ & 0.0046 & $-0.0806^{* *}$ & 0.0186 \\
\hline \multicolumn{5}{|c|}{ Establishment characteristics } \\
\hline Private & $0.3412 * *$ & 0.0059 & $0.1264 * *$ & 0.0218 \\
\hline Size 50-99 & $-0.1105^{* *}$ & 0.0056 & 0.0399 & 0.0217 \\
\hline Size $100-199$ & $-0.1545 * *$ & 0.0062 & $0.0855 * *$ & 0.0246 \\
\hline Size $200-499$ & $-0.1814 * *$ & 0.0067 & $0.1468 * *$ & 0.0266 \\
\hline Size $500+$ & $-0.3939 * *$ & 0.0069 & $0.2181 * *$ & 0.0309 \\
\hline \multicolumn{5}{|c|}{ Regional characteristics } \\
\hline Östra Mellansverige & $-0.1800 * *$ & 0.0062 & -0.0096 & 0.0248 \\
\hline Småland med öarna & $-0.3243 * *$ & 0.0083 & $-0.0852 * *$ & 0.0326 \\
\hline Sydsverige & $-0.2002 * *$ & 0.0066 & $-0.1203^{* *}$ & 0.0259 \\
\hline Västsverige & $-0.2364 * *$ & 0.0060 & $-0.0760 * *$ & 0.0236 \\
\hline Norra Mellansverige & $-0.2329 * *$ & 0.0082 & -0.0601 & 0.0323 \\
\hline Mellersta Norrland & $-0.1806^{* *}$ & 0.0109 & -0.0149 & 0.0435 \\
\hline Övre Norrland & $-0.2685^{* *}$ & 0.0104 & $-0.1051^{*}$ & 0.0410 \\
\hline Log likelihood & $-217,462$ & & $-16,300$ & \\
\hline Wald $\chi^{2}(43)$ & $25,914.2$ & & 2191.9 & \\
\hline Prob $>\chi^{2}$ & 0.0000 & & 0.0000 & \\
\hline Observations & $2,078,377$ & & 48,602 & \\
\hline
\end{tabular}

is less pronounced when it comes to re-employment, but in general the chance of finding a new job after displacement seems to be higher for workers residing in the Stockholm region.

To summarize, the probit regression analyses show that workers employed in the two tradable sectors are most likely to be affected by job loss. But whereas workers employed in tradable services have relatively promising re-employment prospects in the event of displacement, this is not the case for workers employed in manufacturing. If we were to distinguish any specific group particularly hard hit in terms of high displacement risks and low re-employment probabilities that would be young workers, with a low level of education, employed at small manufacturing establishments. 


\section{Econometric analysis of the effects of displacement on earnings}

Previous literature on the effects of job displacement indicates that displaced workers not only suffer in terms of unemployment and wage losses during a shortterm transition period but also face more long-term costs of job loss. Even though most displaced workers get back into new jobs relatively quickly there are several reasons why job loss can lead to long lasting negative effects. Loss of firm- and industry-specific human capital, loss of seniority, high turnover in subsequent shorttenured jobs and multiple job losses are examples of suggested explanations of why displacement may cause negative effects also in the longer run. In this section, we continue by examining the effect of job loss on labor earnings for workers displaced from the different sectors.

\subsection{Data and econometric strategy}

The analysis focuses on displacements that occur in the years between 2000 and 2005. For each year $t$, we have a population of about 1.5 million individuals fulfilling the basic sample restrictions described in Sect. 2.2. ${ }^{26}$ From each of these years we have drawn a $10 \%$ random sample of individuals, giving us a sample with six cohorts including roughly 885,000 individuals. Each individual is followed over a ten-year period $t-5$ to $t+4$. The sample is divided into a treatment group and a comparison group. The treatment group consists of workers who between year $t-1$ and year $t$ were displaced, either through establishment closure or mass dismissal, according to the previously described definition of displacement. The comparison group consists of workers who were not displaced between year $t-1$ and year $t$ (but who may have been displaced later). The sample includes roughly 25,000 displaced workers $(2.8 \%)$ in the treatment group and about 860,000 non-displaced workers in the comparison group.

The most common approach to estimate earnings losses from displacement have until recently been to follow Jacobson et al. (1993) and use some type of fixedeffects model. An alternative that has gained in popularity in the programme evaluation literature is various types of matching methods. The basic idea behind matching is to choose a comparable untreated (non-displaced) worker for each treated (displaced) worker and use these pairs to calculate the effect of the treatment (displacement) on the outcome of interest (earnings). We will use matching as our main estimation strategy and compare the results with those obtained with a fixedeffects specification. A similar approach can be found in a recent paper by Couch and Placzek (2010). Two advantages with matching over conventional parametric estimation techniques is that matching is more explicit in assessing whether or not comparable untreated observations are available for each treated observation and, further, that matching does not rely on the same type of functional form assumptions that traditional parametric approaches typically do. There are numerous papers suggesting that avoiding (potentially incorrect) functional form assumptions and

\footnotetext{
26 The only exception is that we here restrict our attention to individuals aged 25-54 years of age in year $t-1$. This is to ensure that the individuals are of working age during the whole observation period.
} 
imposing a common support condition can be important for reducing selection bias in studies based on observational data. ${ }^{27}$

More specifically, we will estimate the earnings losses from displacement using a conditional difference-in-differences-matching approach suggested by Heckman et al. (1997, 1998). The main parameter we are interested in estimating is the average treatment effect on the treated, ATT, which in our case corresponds to the average effect of displacement for those workers being displaced. The following set of equations gives the basic intuition behind the estimation strategy:

$$
\begin{gathered}
A T T_{t^{+}}=E\left(Y_{1 t+} \mid X_{t-}, D_{t}=1\right)-E\left(Y_{0 t+} \mid X_{t-}, D_{t}=0\right)=A T T+\bar{B} \\
A T T_{t^{-}}=E\left(Y_{1 t-} \mid X_{t-}, D_{t}=1\right)-E\left(Y_{0 t-} \mid X_{t-}, D_{t}=0\right)=\bar{B} \\
A T T_{t^{+}}-A T T_{t^{-}}=A T T+\bar{B}-\bar{B}=A T T
\end{gathered}
$$

where $t^{-}$and $t^{+}$denote time periods before and after potential displacement occurring at time $t, D_{t}=1$ indicate that a worker is displaced at $t$ and $D_{t}=0$ indicates that a worker is not displaced at $t, Y_{1}$ represents earnings in the case of displacement and $Y_{0}$ represents earnings if not displaced, $X$ denotes a set of observed pre-displacement covariates affecting both displacement probability and earnings, and finally $\bar{B}$ represents possible selection bias in the estimation of $A T T$.

Equation (1) represents a conventional cross-sectional matching estimator. This equation rests on an assumption of mean conditional independence, i.e. $E\left(Y_{0 t+} \mid X_{t-}, D_{t}=1\right)=E\left(Y_{0 t+} \mid X_{t-}, D_{t}=0\right)$. This assumption states that if we condition on a sufficiently rich set of pre-treatment covariates, we can use the earnings of non-displaced workers as an approximation of the earnings displaced workers would have received had they not been displaced (the counterfactual outcome). In most empirical settings this is not a realistic assumption since it requires access to very rich data. If there are unobservable characteristics affecting both displacement and earnings, the assumption no longer holds and Eq. (1) will give a biased estimate of ATT. Equation (2) simply states that if we construct a matching estimate for pre-treatment outcomes we would expect to find bias only due to unobserved differences between displaced and non-displaced workers (i.e. the effect of a treatment cannot precede the treatment itself). Equation (3) show that if we take the difference between the post- and pre-treatment matching estimates we can remove the time-invariant portion of the bias.

From the outline above it follows that the conditional difference-in-differences approach do not rely on the likely implausible assumption that we can observe all factors affecting both displacement and earnings. The conditional difference-indifferences-matching strategy extends conventional cross-sectional matching methods because it not only takes care of potential selection bias due to observable differences between displaced and non-displaced workers but also eliminates bias due to time-invariant unobservable differences between the two. But this does not suggest that estimates based on this identification strategy are immune to potential bias. If there are unobservable differences between displaced and non-displaced

\footnotetext{
27 See e.g. Heckman et al. (1997, 1998), Dehejia and Wahba (1999, 2002) and Smith and Todd (2005).
} 
workers that vary over time (i.e. are different in the pre- and post-displacement periods) this is a potential source of remaining bias with our identification strategy.

In the differencing, we let the average earnings during years $t-3$ to $t-1$ represent the pre-treatment outcome. We follow the typical procedure in the literature and base the matching on the predicted probability of displacement, the propensity score (Rosenbaum and Rubin 1983), rather than on the pre-treatment covariates themselves. We use single nearest neighbor matching (with replacement) as our matching algorithm and match each displaced worker to the most comparable non-displaced worker with respect to the propensity score. ${ }^{28}$

The following covariates are included in the propensity score: age, age square, male, level of education (three categories), establishment characteristics (five categories of employment size), region of residence (eight categories), and year of possible displacement. The estimates focusing on all sectors also include sector of employment (three categories). All variables refer to year $t-1$. In addition, the propensity score includes pre-treatment annual earnings for years $t-5$ to $t-1$. The covariates included in the propensity score are standard variables appearing in previous studies based on similar data. ${ }^{29}$

The dependent variable in the analysis is real gross annual earnings (deflated by the 2009 consumer price index). As in most other similar studies the earnings is labor earnings and include no income transfers such as unemployment benefits. ${ }^{30}$ Annual earnings can be considered a function of wage per hour, number of hours worked per week and the number of weeks worked per year. Annual earnings therefore capture the full costs of displacement in terms of lower wages as well as shorter hours and periods of non-employment. In some cases it can be interesting to distinguish between the effects of displacement on these various components. We will return to this issue below.

Descriptive statistics for displaced and non-displaced workers in different sectors are presented in Table 7 in the Appendix.

\subsection{Displacement effects on earnings: econometric results}

We begin by estimating the conditional difference-in-differences-matching estimates of the effect of displacement for workers in all sectors (save for the excluded sectors according to the base sample restrictions in Sect. 2.2). ${ }^{31}$ Figure 6 provides a graphical presentation of the results. The estimated effects in SEK have been converted into percentage losses using the average annual earnings of displaced

\footnotetext{
28 This algorithm trades reduced bias for increased variance (using additional neighbors would raise bias due to increasingly poorer matches but decrease variance because more information would be used to construct the counterfactual for each treated observation). Given the large relative number of nondisplaced workers it might have been preferable to use additional neighbors and a kernel algorithm. The choice of single nearest neighbor is primarily motivated by ease of computability.

29 See e.g. Eliason and Storrie (2006), Carneiro and Portugal (2006), and Huttunen et al. (2011).

30 An exception is Huttunen et al. (2011).

31 The specification of the propensity score on which the matching estimates are based is similar to the probit model for displacement in Table 4. The exception is that the propensity score specification also includes pre-treatment annual earnings for years $t-5$ to $t-1$.
} 


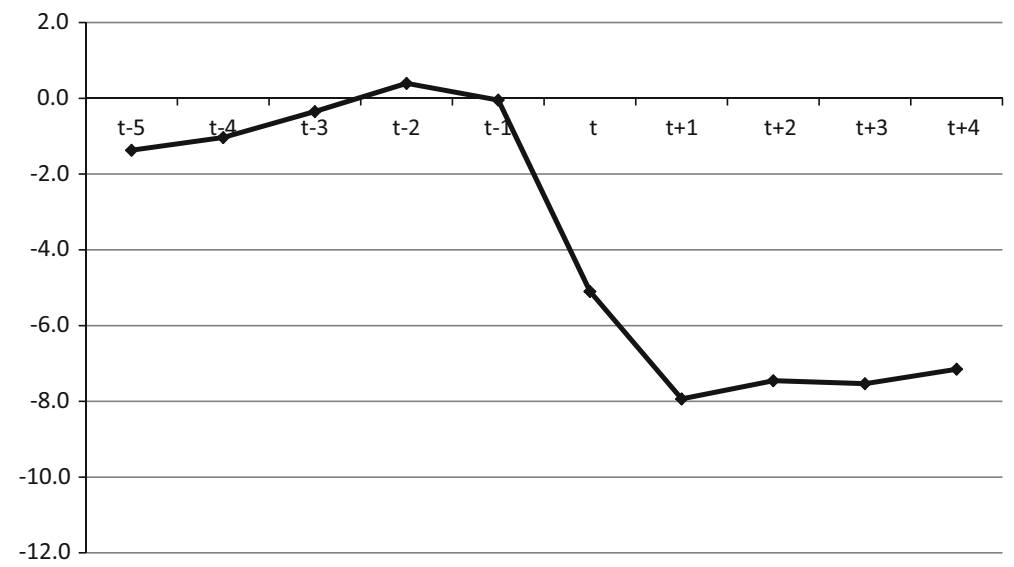

Fig. 6 Matching estimates of the effect of displacement on annual earnings, all sectors (\%). Note Based on the estimates reported in Table 8 in the Appendix, where more detailed information is available

workers during year $t-3$ to $t-1$. Table 8 in the Appendix present parameter estimates and associated standard errors together with some additional details. In the year of displacement, there is a sharp drop in annual earnings. The earnings for displaced workers are about SEK 15,000 lower than would otherwise have been the case. This initial drop corresponds to a reduction in annual earnings with $5 \%$ compared to the pre-displacement level. The earnings decline continues during the first post-displacement year. The estimated effect corresponds to a reduction in annual earnings with $8 \%$ compared to the pre-displacement level. We find no signs of any substantial earnings recovery. In the fourth post-displacement year, annual earnings are still $7 \%$ below the pre-displacement level. The balancing indicators (see Table 8 in the Appendix) suggest that the matching has been fairly successful in balancing differences in observable attributes between the treatment and the comparison group. The mean standardized bias is reduced by roughly a factor of ten and the pseudo $R^{2}$ value drops practically to zero after matching.

When we compare the matching estimates with those obtained using a Jacobson et al. (1993) type of fixed-effects model, we find relatively small differences in the estimated effects (see Table 9 in the Appendix for the latter). This was also the case in Couch and Placzek (2010), who made comparisons between similar estimators.

Our estimates of the effect of displacement for workers in all sectors are fairly similar to those reported by Eliason and Storrie (2006). They focus on displacements in Sweden in 1987 and find an initial earnings reduction corresponding to around $10 \%$ of annual pre-displacement earnings. ${ }^{32}$ The earnings losses following displacement stands out as being rather low in Sweden, and also in some of the other Nordic countries, compared to the effects reported for the United States but also for some other European countries. ${ }^{33}$

\footnotetext{
32 Our own calculations based on reported effects in SEK in relation to displaced workers reported average annual earnings in SEK two years prior to displacement.

33 See e.g. Jacobson et al. (1993) and Couch and Placzek (2010) for results for the United States and the OECD (2013) for a broader review of findings.
} 


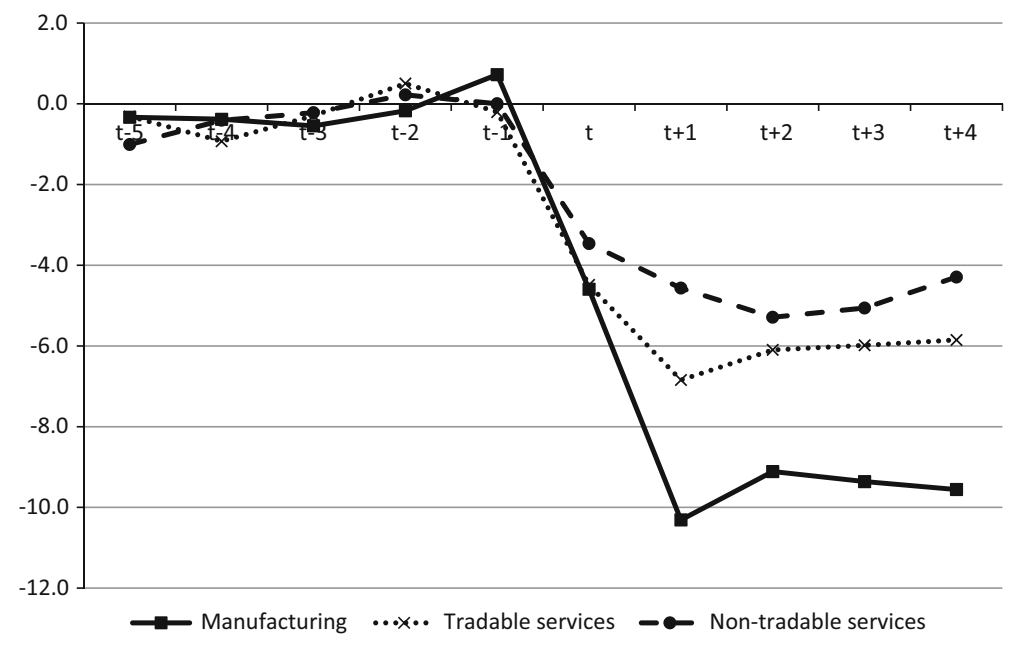

Fig. 7 Matching estimates of the effect of displacement on annual earnings, by sector (\%). Note Based on the estimates reported in Table 10, where more detailed information is available

Figure 7 provides a graphical presentation of the estimated effects of displacement for workers in manufacturing, tradable and non-tradable services (details are presented in Table 10 in the Appendix). The results are based on separate conditional difference-in-differences-matching estimates for the three sectors in question. For all sectors, we observe a significant drop in annual earnings in the year of displacement. The earnings drop continues during the first post-displacement year. Workers displaced from manufacturing experience the largest earnings losses $(10 \%)$, followed by workers displaced from tradable services $(7 \%)$ and workers displaced from non-tradable services $(5 \%) .{ }^{34}$ After the first or second postdisplacement year we see indications of a very modest recovery, but in the fourth post-displacement year earnings are still well below the pre-displacement level. In order to check whether there are any statistical differences between the point estimates for the three sectors, we have calculated $95 \%$ confidence intervals for each point estimate. It turns out that the estimated effect for manufacturing is significantly lower than the estimated effect for non-tradable services in the years $t+1$ to $t+4$ and also significantly lower than the estimated effect for tradable services in year $t+1$. Apart from that, there are no statistical differences between the point estimates.

In Table 1 we have seen that the share of skilled labor is higher in tradable services $(51 \%)$ than in non-tradable services $(37 \%)$ and manufacturing $(27 \%)$ and we know that earnings losses of displaced workers are usually higher among lessskilled workers. ${ }^{35}$ Does the fact that manufacturing has a higher proportion of less-

\footnotetext{
34 Even though the data in Jensen and Kletzer (2006, 2008) do not allow for more formal econometric analyses one can discern similar patterns in the earnings losses among the displaced workers in the United States in the beginning of the 2000s.

35 OECD (2013) Figure 4.10.
} 

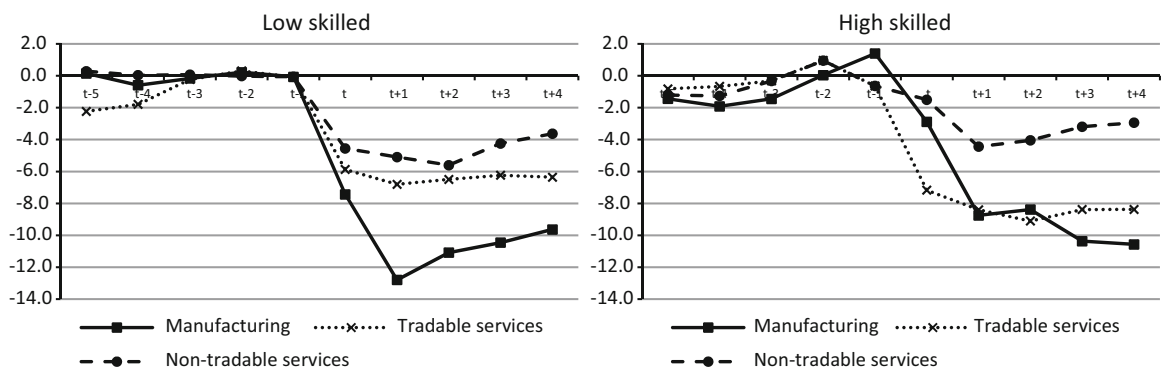

Fig. 8 Matching estimates of the effect of displacement on annual earnings, by sector and level of education (\%). Note low skilled is defined as less than secondary or secondary education (ISCED 0-3) and high skilled as post-secondary education (ISCED 4-6). Percentage effects are calculated as estimate divided by average annual earnings of displaced workers $t-3$ to $t-1$

skilled workers explain the larger earnings losses among the displaced workers in manufacturing? To examine that in Fig. 8 we produce Fig. 7 for skilled and lessskilled workers separately, where the left panel (a) show the profile of annual earnings for less-skilled workers and the right panel (b) for skilled workers. ${ }^{36}$

Some interesting patterns appear in Fig. 8. Firstly, the earnings losses among displaced less-skilled workers in panel (a) are significant in all groups and significantly higher for less skilled workers displaced from manufacturing than displaced less-skilled workers from tradable and non-tradable services. ${ }^{37}$ This is not surprising given the sharply declining employment of less-skilled workers we observe in manufacturing during the studied period (Table 1). Secondly, the earnings losses among displaced skilled workers in panel (b) are different. Here, the earnings losses are significant both for skilled workers displaced from manufacturing $^{38}$ and from tradable services, whereas this is not the case for skilled workers displaced from non-tradable services. However, the earnings losses are not significantly different from each other owing to from which sector the skilled workers are displaced. ${ }^{39}$ In other words, it seems that the large earnings losses we observe in manufacturing are mainly driven by the many displaced less-skilled workers. Nevertheless, we find quite large earnings losses also for displaced skilled workers in manufacturing. Accordingly, the differences in earnings losses depending on displacement sector are not only a result of variations in compositions of labor skills between sectors.

Since earnings losses after displacement can be attributed to the loss of sectorspecific human capital, an explanation to why workers displaced from

\footnotetext{
36 This thought-provoking extension is suggested by one of the anonymous referees.

${ }^{37}$ For the sake of brevity we have not included tables in the Appendix showing the results in Fig. 8 including estimates and confidence intervals. However, we would be more than happy to send them upon request.

38 An exception is displaced skilled workers from manufacturing in period $t+1$.

39 Large standard errors of the point estimates explains why the earnings losses for displaced skilled workers from manufacturing and from tradable services are not significantly higher than for displaced skilled workers from non-tradable service.
} 
Table 5 Labor market status of displaced workers the year after displacement

\begin{tabular}{lllc}
\hline Employment in $t-1$ & \multicolumn{2}{l}{ Labor market status in $t$} & \\
\cline { 2 - 4 } & Employed same sector & Employed new sector & Non employed \\
\hline Manufacturing & 56.1 & 34.4 & 9.5 \\
Tradable services & 67.6 & 24.9 & 7.5 \\
Non-tradable services & 71.6 & 18.3 & 10.1 \\
\hline
\end{tabular}

Share of all the displaced in the sector $(\%)$

manufacturing suffer the largest earnings losses might be that they to a larger extent have to switch sector (leave manufacturing). Ebenstein et al. (2014) find that the negative wage consequences are larger for those who leave manufacturing compared to those that switch industries within manufacturing. In Table 5 we can see that the share of the displaced who find a new job in the same sector at time $t$ is smallest for those that are displaced from manufacturing. In other words, great losses of sector-specific human capital for workers displaced from manufacturing are consistent with the pattern shown in Table 5 and the estimated earnings losses in Fig. 7.

\subsection{Long periods of non-employment or lower wages?}

When comparing the estimated effects of job loss on earnings for workers displaced from the different sectors with the previous results on re-employment opportunities, we find some similarities but also some interesting discrepancies. The relatively low probability of re-employment for workers displaced from manufacturing translates into the highest earnings losses during and following displacement for these workers. This result is perhaps not so surprising since the dependent variable in the earnings analysis is real annual earnings, which among other things capture the costs of job loss in terms of periods of non-employment. The fairly high earnings losses for employees displaced from tradable services are more surprising in this sense. These workers on the one hand face the most promising re-employment opportunities in the event of job loss, but on the other hand suffer relatively high earnings losses from displacement. There are several possible explanations for this seemingly inconsistent story. Workers displaced from tradable services might, for instance, suffer particularly hard from loss of firm- and industry-specific human capital and seniority.

One approach to analyze whether observed earnings losses primarily are due to lower wages in subsequent jobs or mainly a result of periods of non-employment after displacement is to focus on earnings effects for workers who have found new jobs after displacement. If we condition on the workers being employed after displacement, the effect of displacement on annual earnings must predominantly (or at least to a larger extent) be due to lower wages in the new job. It is important to note that this type of conditioning on the future implies that we are no longer estimating the full costs of displacement on annual earnings. The effect that operates through spells of non-employment has (partly) been ruled out by definition. 


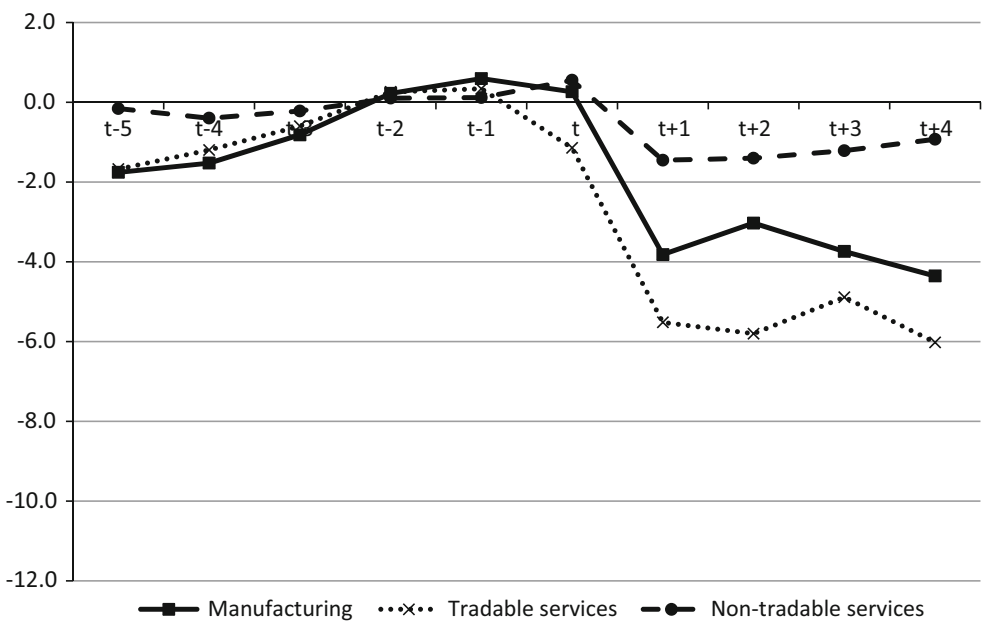

Fig. 9 Matching estimates of the effect of displacement on annual earnings, by sector (\%). Conditional on being employed during the years $t$ to $t+4$. Note Based on the estimates reported in Table 11 where more detailed information is available

Figure 9 provides a graphical presentation of the estimated effects of displacement when we condition on the displaced workers being employed in new jobs during the years $t$ to $t+4$ (details are presented in Table 11 in the Appendix). ${ }^{40}$ Note that we follow the official definition of employment status in Sweden and focus on the workers being employed in November each year. The workers are therefore not necessarily employed full-time during the whole year but may have experienced spells of non-employment during some parts of the year. If we compare with the previous figure, there are some striking changes in the results. One is that workers displaced from tradable services now experience the largest earnings losses (around $6 \%$ ), followed by workers displaced from manufacturing (around $4 \%$ ). The other is that the effect of displacement for workers in non-tradable services no longer is statistically significant (except for year $t+1$ ).

We interpret the relatively large reduction in estimated effects for workers displaced from manufacturing and non-tradable services as an indication that these workers find new jobs that pay wages that are fairly comparable with the wages in the pre-displacement jobs. This is particularly the case for workers displaced from non-tradable services. The fact that we find almost no reduction in the estimated effect for workers displaced from tradable services when conditioning on future employment indicate that these workers to a greater extent accept new jobs that pay lower wages than the pre-displacement jobs.

\footnotetext{
${ }^{40}$ We also condition on that non-displaced workers in the comparison group are employed during the years $t$ to $t+4$.
} 


\section{Concluding remarks}

We have examined the costs of displacement in tradable and non-tradable sectors in Sweden in the 2000s. To this end we divided the economy into three sectors, manufacturing, tradable and non-tradable services, where the former two are expected to be tradable (at least potentially). Our results indicate that the probability of displacement, controlling for factors that might impact on displacement, is higher in the tradable sectors, particularly in tradable services. However, when it comes to re-employment in the event of displacement the prospects for workers previously employed in tradable services are more promising than for workers earlier employed in manufacturing. Relatively low re-employment probabilities for workers displaced from manufacturing, and that such workers often are forced to find a new job outside of manufacturing, are also reflected in the relatively high income losses that this group of workers have after displacement. In other words, our results indicate that those displaced from tradable service fare better than those displaced from manufacturing.

Characteristic traits of the tradable service sector are that it is highly skillintensive and that the skill intensity grows faster there than in the other sectors. Over the last 20 years employment in tradable services has expanded, while the employment in manufacturing has contracted. Furthermore, in contrast to manufacturing that is more evenly spread out over Sweden, ${ }^{41}$ tradable services are concentrated to the larger local labor market regions (big cities). ${ }^{42}$ In sum, tradable services appear to be an expanding, dynamic and human capital intensive sector.

The workers displaced from tradable services nonetheless seem to suffer from relatively high income losses. Unlike those displaced in manufacturing, whose earnings losses appear to be due to longer spells of non-employment, the earnings losses of those displaced in tradable services seem to emanate from lower wages in the new jobs compared to the wages in the pre-displacement jobs. Such wage decreases might indicate depreciations of firm- and industry-specific human capital and loss of seniority among those displaced from tradable services. However, to draw more definite conclusion on that issue calls for a more careful analysis and is an interesting question for further research.

Acknowledgments Financial support from Swedish Research Council for Health, Working Life and Welfare is gratefully acknowledged.

Open Access This article is distributed under the terms of the Creative Commons Attribution 4.0 International License (http://creativecommons.org/licenses/by/4.0/), which permits unrestricted use, distribution, and reproduction in any medium, provided you give appropriate credit to the original author(s) and the source, provide a link to the Creative Commons license, and indicate if changes were made.

\footnotetext{
41 Specific manufacturing industries are of course strongly regionally concentrated.

42 In Sweden, there is a strong positive and significant correlation on regional level between the share of employment in tradable service and the size of the local labor market region, whereas the same correlation with the share of employment in manufacturing is insignificant (Eliasson et al. 2012b, figures 6.5 and 6.6). A similar pattern can be observed in the United States (Jensen 2011, chapter 8).
} 


\section{Appendix}

See Tables 6, 7, 8, 9, 10 and 11.

Table 6 Manufacturing, tradable services and non-tradable services: industries, locational Ginis and employment

\begin{tabular}{|c|c|c|c|}
\hline $\begin{array}{l}\text { NACE } \\
\text { code }\end{array}$ & Industry & $\begin{array}{l}\text { Gini } \\
2005\end{array}$ & $\begin{array}{l}\text { Employment } \\
2005\end{array}$ \\
\hline \multicolumn{4}{|c|}{ Manufacturing } \\
\hline 296 & Manufacture of weapons and ammunition & 0.958 & 3532 \\
\hline 314 & Manufacture of accumulators, primary cells and batteries & 0.952 & 486 \\
\hline 272 & Manufacture of tubes & 0.925 & 8109 \\
\hline 154 & Manufacture of vegetable and animal oils and fats & 0.875 & 1257 \\
\hline 271 & Manufacture of basic iron and steel and ferro-alloys & 0.869 & 13,027 \\
\hline 265 & Manufacture of cement, lime and plaster & 0.869 & 681 \\
\hline 273 & Other first processing of iron and steel & 0.854 & 3289 \\
\hline 342 & Manufacture of bodies for motor vehicles and trailers & 0.851 & 8710 \\
\hline 274 & Manufacture of basic precious and non-ferrous metals & 0.841 & 6735 \\
\hline 275 & Casting of metals & 0.839 & 3577 \\
\hline 353 & Manufacture of aircraft and spacecraft & 0.837 & 8464 \\
\hline 297 & Manufacture of domestic appliances n.e.c. & 0.810 & 6390 \\
\hline 311 & Manufacture of electric motors, generators and transformers & 0.806 & 6050 \\
\hline 230 & Manufacture of coke, petroleum products and nuclear fuel & 0.805 & 2801 \\
\hline 261 & Manufacture of glass and glass products & 0.803 & 4213 \\
\hline 152 & Processing and preserving of fish and fish products & 0.774 & 2105 \\
\hline 202 & Manufacture of veneer sheets etc. & 0.767 & 1740 \\
\hline 354 & Manufacture of motorcycles and bicycles & 0.755 & 1184 \\
\hline 268 & Manufacture of other non-metallic mineral products & 0.747 & 1928 \\
\hline 341 & Manufacture of motor vehicles & 0.730 & 43,148 \\
\hline 364 & Manufacture of sports goods & 0.722 & 697 \\
\hline 312 & $\begin{array}{l}\text { Manufacture of electricity distribution and control } \\
\text { apparatus }\end{array}$ & 0.715 & 7581 \\
\hline 251 & Manufacture of rubber products & 0.708 & 9116 \\
\hline 190 & Tanning and dressing of leather etc. & 0.706 & 1264 \\
\hline 313 & Manufacture of insulated wire and cable & 0.702 & 3528 \\
\hline 315 & Manufacture of lighting equipment and electric lamps & 0.693 & 2894 \\
\hline 211 & Manufacture of pulp, paper and paperboard & 0.690 & 28,207 \\
\hline 262 & Manufacture of ceramic goods other etc. & 0.671 & 2194 \\
\hline 157 & Manufacture of prepared animal feeds & 0.670 & 942 \\
\hline 160 & Manufacture of tobacco products & 0.668 & 1093 \\
\hline 365 & Manufacture of games and toys & 0.661 & 601 \\
\hline 153 & Processing and preserving of fruit and vegetables & 0.657 & 3686 \\
\hline 361 & Manufacture of furniture & 0.651 & 18,774 \\
\hline
\end{tabular}


Table 6 continued

\begin{tabular}{|c|c|c|c|}
\hline $\begin{array}{l}\text { NACE } \\
\text { code }\end{array}$ & Industry & $\begin{array}{l}\text { Gini } \\
2005\end{array}$ & $\begin{array}{l}\text { Employment } \\
2005\end{array}$ \\
\hline 351 & Building and repairing of ships and boats & 0.629 & 5095 \\
\hline 343 & Manufacture of parts for motor vehicles and engines & 0.626 & 27,338 \\
\hline 352 & Manufacture of railway and tramway locomotives etc. & 0.624 & 4177 \\
\hline 300 & Manufacture of office machinery and computers & 0.621 & 3772 \\
\hline 201 & Sawmilling and planing of wood, impregnation of wood & 0.619 & 14,966 \\
\hline 323 & Manufacture of television and radio receivers etc. & 0.616 & 1723 \\
\hline 212 & Manufacture of articles of paper and paperboard & 0.612 & 10,184 \\
\hline 245 & Manufacture of soap and detergents etc. & 0.601 & 1904 \\
\hline 286 & Manufacture of cutlery, tools and general hardware & 0.598 & 12,519 \\
\hline 267 & Cutting, shaping and finishing of stone & 0.591 & 1060 \\
\hline 321 & Manufacture of electronic components & 0.587 & 3198 \\
\hline 282 & $\begin{array}{l}\text { Manufacture of tanks, reservoirs and containers of metal } \\
\text { etc. }\end{array}$ & 0.585 & 1322 \\
\hline 159 & Manufacture of beverages & 0.581 & 5574 \\
\hline 246 & Manufacture of other chemical products & 0.579 & 3222 \\
\hline 243 & Manufacture of paints etc. & 0.566 & 3759 \\
\hline 170 & Manufacture of textiles & 0.560 & 14,376 \\
\hline 293 & Manufacture of agricultural and forestry machinery & 0.556 & 3484 \\
\hline 244 & Manufacture of pharmaceuticals etc. & 0.551 & 19,303 \\
\hline 241 & Manufacture of basic chemicals & 0.547 & 10,601 \\
\hline 180 & Manufacture of wearing apparel & 0.547 & 2275 \\
\hline 203 & Manufacture of builders' carpentry and joinery & 0.546 & 18,009 \\
\hline 287 & Manufacture of other fabricated metal products & 0.543 & 13,911 \\
\hline 205 & Manufacture of other products of wood and cork & 0.543 & 2013 \\
\hline 294 & Manufacture of machine-tools & 0.541 & 7666 \\
\hline 322 & Manufacture of television and radio transmitters etc. & 0.538 & 20,048 \\
\hline 204 & Manufacture of wooden containers & 0.530 & 2153 \\
\hline 291 & Manufacture of machinery for mechanical power & 0.530 & 18,061 \\
\hline 151 & Production, processing and preserving of meat & 0.525 & 14,930 \\
\hline 156 & Manufacture of grain mill and starch products & 0.498 & 1727 \\
\hline 295 & Manufacture of other special purpose machinery & 0.498 & 26,191 \\
\hline 333 & Manufacture of industrial process control equipment & 0.491 & 1594 \\
\hline 334 & $\begin{array}{l}\text { Manufacture of optical instruments and photographic } \\
\text { equipment }\end{array}$ & 0.486 & 1530 \\
\hline 252 & Manufacture of plastic products & 0.483 & 19,321 \\
\hline 362 & Manufacture of jewellery and related articles & 0.475 & 740 \\
\hline 284 & Forging, pressing, stamping and roll forming of metal etc. & 0.473 & 2897 \\
\hline 292 & Manufacture of other general purpose machinery & 0.460 & 30,789 \\
\hline 331 & $\begin{array}{l}\text { Manufacture of medical, surgical and orthopaedic } \\
\text { equipment }\end{array}$ & 0.452 & 10,137 \\
\hline 370 & Recycling & 0.430 & 2176 \\
\hline
\end{tabular}


Table 6 continued

\begin{tabular}{|c|c|c|c|}
\hline $\begin{array}{l}\text { NACE } \\
\text { code }\end{array}$ & Industry & $\begin{array}{l}\text { Gini } \\
2005\end{array}$ & $\begin{array}{l}\text { Employment } \\
2005\end{array}$ \\
\hline 155 & Manufacture of dairy products & 0.429 & 8270 \\
\hline 281 & Manufacture of structural metal products & 0.427 & 13,358 \\
\hline 332 & $\begin{array}{l}\text { Manufacture of instruments for measuring, testing, } \\
\text { navigating }\end{array}$ & 0.402 & 9981 \\
\hline 285 & Treatment and coating of metals etc. & 0.398 & 32,514 \\
\hline 266 & Manufacture of articles of concrete, plaster and cement & 0.382 & 6735 \\
\hline 316 & Manufacture of electrical equipment n.e.c. & 0.366 & 3200 \\
\hline 158 & Manufacture of other food products & 0.299 & 23,056 \\
\hline 366 & Miscellaneous manufacturing n.e.c. & 0.263 & 23,427 \\
\hline 221 & Publishing & 0.248 & 24,887 \\
\hline 222 & Printing and service activities related to printing & 0.246 & 20,214 \\
\hline \multicolumn{3}{|c|}{ Total employment manufacturing } & 706,834 \\
\hline \multicolumn{4}{|c|}{ Tradable services } \\
\hline 611 & Sea and coastal water transport & 0.890 & 11,247 \\
\hline 732 & $\begin{array}{l}\text { Research and development on social sciences and } \\
\text { humanities }\end{array}$ & 0.609 & 2906 \\
\hline 726 & Other computer related activities & 0.581 & 1339 \\
\hline 621 & Scheduled air transport & 0.575 & 5782 \\
\hline 622 & Non-scheduled air transport & 0.549 & 1651 \\
\hline 924 & News agency activities & 0.544 & 2112 \\
\hline 652 & Other financial intermediation & 0.531 & 10,757 \\
\hline 723 & Data processing & 0.517 & 9095 \\
\hline 552 & $\begin{array}{l}\text { Camping sites and other provision of short-stay } \\
\text { accommodation }\end{array}$ & 0.514 & 2482 \\
\hline 921 & Motion picture and video activities & 0.476 & 6082 \\
\hline 671 & Activities auxiliary to financial intermediation & 0.469 & 3158 \\
\hline 612 & Inland water transport & 0.467 & 1471 \\
\hline 911 & Activities of business and employers' organizations & 0.462 & 5447 \\
\hline 922 & Radio and television activities & 0.457 & 10,044 \\
\hline 631 & Cargo handling and storage & 0.456 & 9222 \\
\hline 526 & Retail sale not in stores & 0.447 & 10,372 \\
\hline 731 & $\begin{array}{l}\text { Research and development on natural sciences and } \\
\text { engineering }\end{array}$ & 0.436 & 20,888 \\
\hline 712 & Renting of other transport equipment & 0.429 & 720 \\
\hline 512 & Wholesale of agricultural raw materials and live animals & 0.408 & 4419 \\
\hline 672 & Activities auxiliary to insurance and pension funding & 0.404 & 5173 \\
\hline 725 & Maintenance and repair of office and computing machinery & 0.396 & 3434 \\
\hline 601 & Transport via railways & 0.378 & 8422 \\
\hline 711 & Renting of automobiles & 0.370 & 1517 \\
\hline 660 & Insurance and pension funding & 0.365 & 20,553 \\
\hline 410 & Collection, purification and distribution of water & 0.354 & 2382 \\
\hline 642 & Telecommunications & 0.343 & 26,209 \\
\hline
\end{tabular}


Table 6 continued

\begin{tabular}{|c|c|c|c|}
\hline $\begin{array}{l}\text { NACE } \\
\text { code }\end{array}$ & Industry & $\begin{array}{l}\text { Gini } \\
2005\end{array}$ & $\begin{array}{l}\text { Employment } \\
2005\end{array}$ \\
\hline 634 & Activities of other transport agencies & 0.333 & 22,406 \\
\hline 511 & Wholesale on a fee or contract basis & 0.332 & 8503 \\
\hline 722 & Software consultancy & 0.327 & 75,241 \\
\hline 555 & Canteens and catering & 0.322 & 8215 \\
\hline 721 & Hardware consultancy & 0.322 & 1698 \\
\hline 912 & Activities of trade unions & 0.320 & 8058 \\
\hline 455 & Renting of construction or demolition equipment etc. & 0.314 & 3052 \\
\hline 632 & Other supporting transport activities & 0.313 & 14,609 \\
\hline 923 & Other entertainment activities & 0.311 & 19,185 \\
\hline 744 & Advertising & 0.311 & 24,833 \\
\hline 519 & Other wholesale & 0.308 & 1235 \\
\hline 633 & Activities of travel agencies and tour operators etc. & 0.303 & 10,765 \\
\hline 803 & Higher education & 0.300 & 45,973 \\
\hline 514 & Wholesale of household goods & 0.290 & 51,385 \\
\hline 504 & Sale, maintenance and repair of motorcycles etc. & 0.288 & 1869 \\
\hline 513 & Wholesale of food, beverages and tobacco & 0.283 & 26,658 \\
\hline 651 & Monetary intermediation & 0.278 & 41,986 \\
\hline 852 & Veterinary activities & 0.271 & 3229 \\
\hline 741 & Legal, accounting and auditing activities etc. & 0.267 & 75,734 \\
\hline 746 & Investigation and security activities & 0.261 & 15,884 \\
\hline 748 & Miscellaneous business activities n.e.c. & 0.260 & 42,128 \\
\hline 743 & Technical testing and analysis & 0.259 & 6179 \\
\hline 503 & Sale of motor vehicle parts and accessories & 0.248 & 9141 \\
\hline 518 & Wholesale of machinery, equipment and supplies & 0.243 & 54,078 \\
\hline 401 & Production and distribution of electricity & 0.232 & 20,424 \\
\hline 742 & Architectural, engineering and technical consultancy & 0.230 & 58,115 \\
\hline 525 & Retail sale of second-hand goods in stores & 0.223 & 1899 \\
\hline 714 & Renting of personal and household goods n.e.c. & 0.219 & 1733 \\
\hline 403 & Steam and hot water supply & 0.209 & 5410 \\
\hline \multicolumn{3}{|c|}{ Total employment tradable services } & 850,815 \\
\hline \multicolumn{4}{|c|}{ Non-tradable services } \\
\hline 752 & Provision of services to the community as a whole & 0.235 & 75,240 \\
\hline 451 & Site preparation & 0.189 & 21,141 \\
\hline 703 & Real estate activities on a fee or contract basis & 0.188 & 23,765 \\
\hline 515 & Wholesale of non-agricultural intermediate products etc. & 0.186 & 48,028 \\
\hline 753 & Compulsory social security activities & 0.173 & 17,985 \\
\hline 713 & Renting of other machinery and equipment & 0.170 & 6755 \\
\hline 551 & Hotels & 0.167 & 29,573 \\
\hline 927 & Other recreational activities & 0.166 & 12,852 \\
\hline 745 & Labour recruitment and provision of personnel & 0.165 & 40,726 \\
\hline 925 & Library, archives, museums and other cultural activities & 0.162 & 17,128 \\
\hline
\end{tabular}


Table 6 continued

\begin{tabular}{|c|c|c|c|}
\hline $\begin{array}{l}\text { NACE } \\
\text { code }\end{array}$ & Industry & $\begin{array}{l}\text { Gini } \\
2005\end{array}$ & $\begin{array}{l}\text { Employment } \\
2005\end{array}$ \\
\hline 900 & Sewage and refuse disposal, sanitation and similar activities & 0.161 & 12,701 \\
\hline 527 & Repair of personal and household goods & 0.159 & 5071 \\
\hline 505 & Retail sale of automotive fuel & 0.157 & 13,848 \\
\hline 926 & Sporting activities & 0.142 & 28,866 \\
\hline 853 & Social work activities & 0.135 & 376,304 \\
\hline 751 & Administration of the State & 0.129 & 145,563 \\
\hline 747 & Industrial cleaning & 0.128 & 48,382 \\
\hline 553 & Restaurants & 0.127 & 70,108 \\
\hline 501 & Sale of motor vehicles & 0.122 & 30,786 \\
\hline 641 & Post and courier activities & 0.119 & 40,405 \\
\hline 522 & $\begin{array}{l}\text { Retail sale of food, beverages and tobacco in specialized } \\
\text { stores }\end{array}$ & 0.116 & 15,262 \\
\hline 502 & Maintenance and repair of motor vehicles & 0.113 & 24,168 \\
\hline 802 & Secondary education & 0.110 & 53,608 \\
\hline 804 & Adult and other education & 0.106 & 40,690 \\
\hline 523 & $\begin{array}{l}\text { Retail sale of pharmaceutical goods, cosmetic and toilet } \\
\text { articles }\end{array}$ & 0.101 & 14,132 \\
\hline 454 & Building completion & 0.086 & 37,108 \\
\hline 851 & Human health activities & 0.082 & 306,467 \\
\hline 702 & Letting of own property & 0.080 & 45,469 \\
\hline 452 & Building of complete constructions or parts thereof etc. & 0.078 & 119,378 \\
\hline 930 & Other service activities & 0.078 & 35,074 \\
\hline 524 & Other retail sale of new goods in specialized stores & 0.074 & 119,236 \\
\hline 453 & Building installation & 0.073 & 69,255 \\
\hline 913 & Activities of other membership organizations & 0.068 & 48,503 \\
\hline 521 & Retail sale in non-specialized stores & 0.065 & 80,097 \\
\hline 602 & Other land transport & 0.059 & 110,497 \\
\hline 801 & Primary education & 0.040 & 299,432 \\
\hline \multicolumn{3}{|c|}{ Total employment non-tradable services } & $2,483,603$ \\
\hline
\end{tabular}




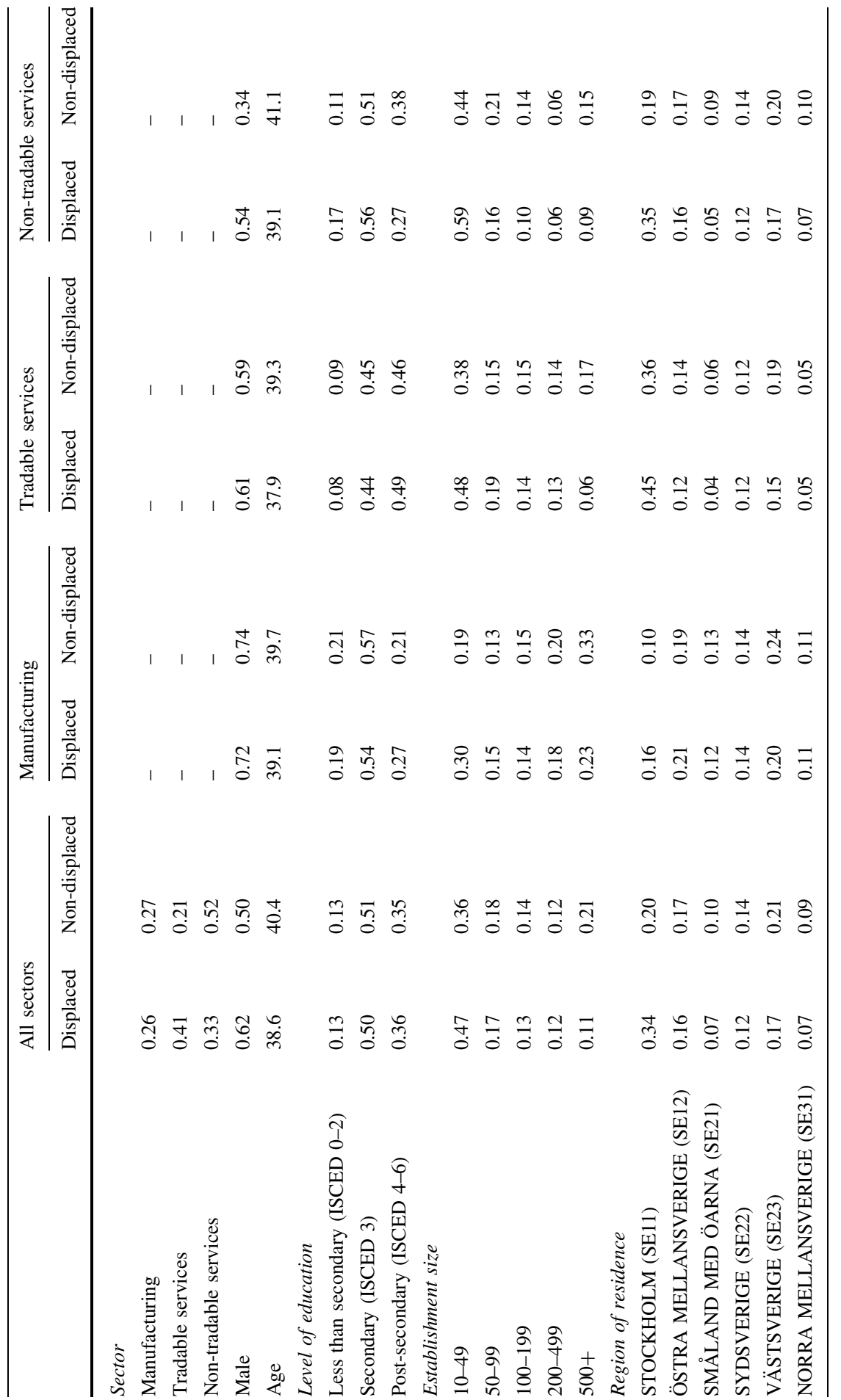




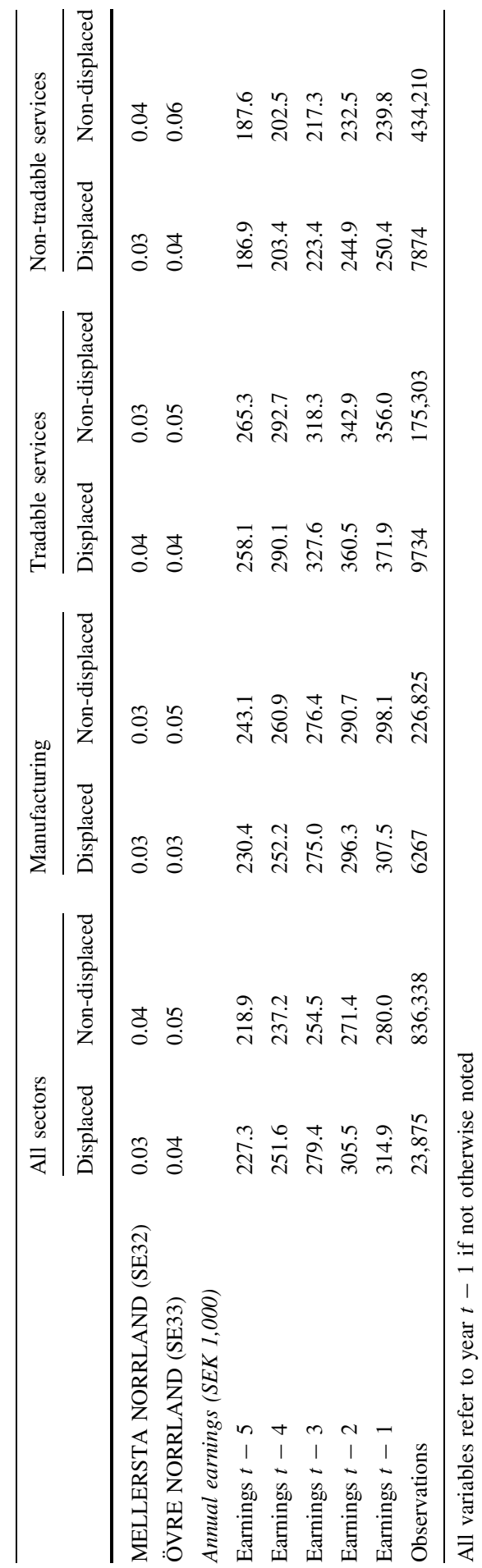


Table 8 Matching estimates of the effect of displacement on annual earnings for all sectors

\begin{tabular}{|c|c|c|}
\hline & SEK & $\%$ \\
\hline$t-5$ & $\begin{array}{l}-4,114 * * \\
(1,318)\end{array}$ & -1.4 \\
\hline$t-4$ & $\begin{array}{l}-3,103 * * \\
(1,111)\end{array}$ & -1.0 \\
\hline$t-3$ & $\begin{array}{l}-1,044 \\
(891)\end{array}$ & -0.3 \\
\hline$t-2$ & $\begin{array}{l}1,182 \\
(619)\end{array}$ & 0.4 \\
\hline$t-1$ & $\begin{array}{l}-138 \\
(888)\end{array}$ & 0.0 \\
\hline$t$ & $\begin{array}{l}-15,295^{* *} \\
(1,563)\end{array}$ & -5.1 \\
\hline$t+1$ & $\begin{array}{l}-23,802 * * \\
(1,873)\end{array}$ & -7.9 \\
\hline$t+2$ & $\begin{array}{l}-22,364 \\
(1,654)\end{array}$ & -7.5 \\
\hline$t+3$ & $\begin{array}{l}-22,596^{* *} \\
(1,981)\end{array}$ & -7.5 \\
\hline$t+4$ & $\begin{array}{l}-21,452 * * \\
(1,805)\end{array}$ & -7.2 \\
\hline \multicolumn{3}{|l|}{ Balancing indicators } \\
\hline Mean bias before & 11.9 & \\
\hline Mean bias after & 1.0 & \\
\hline Pseudo $R^{2}$ before & 0.052 & \\
\hline Pseudo $R^{2}$ after & 0.001 & \\
\hline Untreated on support & 836,338 & \\
\hline Treated on support & 23,875 & \\
\hline
\end{tabular}

The estimated parameters are based on conditional difference-in-differences (DID) propensity score matching using single nearest neighbor. For details on the specification of the propensity score, see Sect. 4.1. Approximate standard errors in parentheses. **, * Significance at the 1 and $5 \%$ levels respectively. Percentage effects are calculated as estimate divided by average annual earnings of displaced workers $t-3$ to $t-1$. The balancing indicators compare the distribution of covariates in the propensity score before and after matching to assess if the matching has been successful (enough) in balancing differences between the treatment and the comparison group. The standardized bias of a covariate is defined as the difference of the sample means in the treatment and the comparison group as a percentage of the square root of the average of the sample variance in the two groups (see Rosenbaum and Rubin 1985). The table reports the mean value (over all covariates) of this bias and the value should drop considerably after matching due to a more similar distribution of covariates in the treatment and comparison group. The pseudo $R^{2}$ indicates how well the covariates in the propensity score explain the probability of displacement. After matching, the value should be fairly low because there should be no systematic differences in the distribution of covariates between the treatment and the comparison group 
Table 9 Fixed-effects estimates of the effect of displacement on annual earnings for all sectors

\begin{tabular}{llr}
\hline & SEK & $\%$ \\
\hline$t$ & $-10,698$ & -3.6 \\
$t+1$ & $-19,967$ & -6.7 \\
$t+2$ & $-19,483$ & -6.5 \\
$t+3$ & $-17,828$ & -5.9 \\
$t+4$ & $-16,591$ & -5.5 \\
Observations & & 860,213 \\
\hline
\end{tabular}

The estimated parameters are based on a fixed-effects regression model with the following specification: $y_{i t}=\alpha_{i}+\gamma_{t}+\sum_{k=-3}^{4} D_{i t}^{k} \delta_{k}+\sum_{k=-3}^{4} C_{i t}^{k} \theta_{k}+\epsilon_{i t}$, where $y_{i t}$ is real gross annual earnings, $\alpha_{i}$ is the individual fixed effect, $\gamma_{t}$ is a set of time dummies that control for year-specific effects, $D_{i t}^{k}$ is a set of dummy variables capturing the event of displacement, $C_{i t}^{k}$ is at set of dummy variables for each year in the cohort, and finally $\epsilon_{i t}$ is an error term assumed to have constant variance and to be uncorrelated across cohortindividuals and time, but may be correlated between individuals who appear in multiple cohorts. $D_{i t}^{k}=1$ if at time $t$ worker $i$ is $k$ years after displacement or $-k$ years before displacement. The parameters $\delta_{k}$ capture the difference in earnings before, during and after the year of displacement between displaced workers in the treatment group and non-displaced workers in the comparison group. We have estimated the model both with and without controls for time-varying individual characteristics. Since the results are very similar we restrict the presentation above to a specification without individual controls. Percentage effects are calculated as estimate divided by average annual earnings of displaced workers $t-3$ to $t-1$

Table 10 Matching estimates of the effect of displacement on annual earnings by sector

\begin{tabular}{|c|c|c|c|c|c|c|}
\hline & \multicolumn{2}{|c|}{ Manufacturing } & \multicolumn{2}{|c|}{ Tradable services } & \multicolumn{2}{|c|}{ Non-tradable services } \\
\hline & SEK & $\%$ & SEK & $\%$ & SEK & $\%$ \\
\hline$t-5$ & $\begin{array}{l}-0,983 \\
(1,828)\end{array}$ & -0.3 & $\begin{array}{l}-1,107 \\
(2,570)\end{array}$ & -0.3 & $\begin{array}{l}-2,420 \\
(1,385)\end{array}$ & -1.0 \\
\hline$t-4$ & $\begin{array}{l}-1,127 \\
(1,514)\end{array}$ & -0.4 & $\begin{array}{l}-3,283 \\
(1,988)\end{array}$ & -0.9 & $\begin{array}{l}-0,981 \\
(1,176)\end{array}$ & -0.4 \\
\hline$t-3$ & $\begin{array}{l}-1,602 \\
(0,952)\end{array}$ & -0.5 & $\begin{array}{l}-1,044 \\
(1,962)\end{array}$ & -0.3 & $\begin{array}{l}-0,530 \\
(0,774)\end{array}$ & -0.2 \\
\hline$t-2$ & $\begin{array}{l}-0,510 \\
(0,665)\end{array}$ & -0.2 & $\begin{array}{l}1,774 \\
(1,239)\end{array}$ & 0.5 & $\begin{array}{l}0,530 \\
(0,533)\end{array}$ & 0.2 \\
\hline$t-1$ & $\begin{array}{l}2,113^{*} \\
(1,011)\end{array}$ & 0.7 & $\begin{array}{l}-0,730 \\
(1,645)\end{array}$ & -0.2 & $\begin{array}{l}0,001 \\
(0,746)\end{array}$ & 0.0 \\
\hline$t$ & $\begin{array}{l}-13,462 * * \\
(1,926)\end{array}$ & -4.6 & $\begin{array}{l}-15,857^{* *} \\
(3,534)\end{array}$ & -4.5 & $\begin{array}{l}-8,300^{* *} \\
(1,387)\end{array}$ & -3.5 \\
\hline$t+1$ & $\begin{array}{l}-30,203 * * \\
(2,130)\end{array}$ & -10.3 & $\begin{array}{l}-24,182 * * \\
(3,688)\end{array}$ & -6.8 & $\begin{array}{l}-10,947 * * \\
(1,563)\end{array}$ & -4.6 \\
\hline$t+2$ & $\begin{array}{l}-26,692 * * \\
(2,376)\end{array}$ & -9.1 & $\begin{array}{l}-21,541 * * \\
(3,824)\end{array}$ & -6.1 & $\begin{array}{l}-12,674 * * \\
(1,729)\end{array}$ & -5.3 \\
\hline$t+3$ & $\begin{array}{l}-27,418 * * \\
(2,482)\end{array}$ & -9.4 & $\begin{array}{l}-21,143^{* *} \\
(4,077)\end{array}$ & -6.0 & $\begin{array}{l}-12,125^{* *} \\
(1,997)\end{array}$ & -5.1 \\
\hline
\end{tabular}


Table 10 continued

\begin{tabular}{|c|c|c|c|c|c|c|}
\hline & \multicolumn{2}{|c|}{ Manufacturing } & \multicolumn{2}{|c|}{ Tradable services } & \multicolumn{2}{|c|}{ Non-tradable services } \\
\hline & SEK & $\%$ & SEK & $\%$ & SEK & $\%$ \\
\hline$t+4$ & $\begin{array}{l}-27,998 * * \\
(2,827)\end{array}$ & -9.6 & $\begin{array}{l}-20,673 * * \\
(4,368)\end{array}$ & -5.9 & $\begin{array}{l}-10,287 * * \\
(2,000)\end{array}$ & -4.3 \\
\hline \multicolumn{7}{|l|}{ Balancing indicators } \\
\hline Mean bias before & 7.7 & & 7.6 & & 10.4 & \\
\hline Mean bias after & 1.2 & & 0.8 & & 1.0 & \\
\hline Pseudo $R^{2}$ before & 0.031 & & 0.033 & & 0.050 & \\
\hline Pseudo $R^{2}$ after & 0.001 & & 0.001 & & 0.001 & \\
\hline Untreated on support & 226,825 & & 175,303 & & 434,210 & \\
\hline Treated on support & 6,267 & & 9,733 & & 7,874 & \\
\hline
\end{tabular}

The estimated parameters are based on conditional difference-in-differences (DID) propensity score matching using single nearest neighbor. For details on the specification of the propensity scores, see Sect. 4.1. Approximate standard errors in parentheses. **, * Significance at the 1 and $5 \%$ levels. Percentage effects are calculated as estimate divided by average annual earnings of displaced workers $t-3$ to $t-1$. See Table 8 for an explanation of the balancing indicators

Table 11 Matching estimates of the effect of displacement on annual earnings by sector. Conditional on being employed during the years $t$ to $t+4$

\begin{tabular}{|c|c|c|c|c|c|c|}
\hline & \multicolumn{2}{|c|}{ Manufacturing } & \multicolumn{2}{|c|}{ Tradable services } & \multicolumn{2}{|c|}{ Non-tradable services } \\
\hline & SEK & $\%$ & SEK & $\%$ & SEK & $\%$ \\
\hline$t-5$ & $\begin{array}{l}-5,284 * * \\
(1,991)\end{array}$ & -1.8 & $\begin{array}{l}-6,030^{*} \\
(2,684)\end{array}$ & -1.7 & $\begin{array}{l}-0,394 \\
(1,531)\end{array}$ & -0.2 \\
\hline$t-4$ & $\begin{array}{l}-4,586^{* * *} \\
(1,644)\end{array}$ & -1.5 & $\begin{array}{l}-4,307 \\
(2,236)\end{array}$ & -1.2 & $\begin{array}{l}-0,993 \\
(1,282)\end{array}$ & -0.4 \\
\hline$t-3$ & $\begin{array}{l}-2,459 * \\
(1,042)\end{array}$ & -0.8 & $\begin{array}{l}-2,154 \\
(1,484)\end{array}$ & -0.6 & $\begin{array}{l}-0,547 \\
(0,846)\end{array}$ & -0.2 \\
\hline$t-2$ & $\begin{array}{l}0,673 \\
(0,749)\end{array}$ & 0.2 & $\begin{array}{l}0,935 \\
(1,038)\end{array}$ & 0.3 & $\begin{array}{l}0,255 \\
(0,565)\end{array}$ & 0.1 \\
\hline$t-1$ & $\begin{array}{l}1,786 \\
(1,124)\end{array}$ & 0.6 & $\begin{array}{l}1,219 \\
(1,607)\end{array}$ & 0.3 & $\begin{array}{l}0,292 \\
(0,804)\end{array}$ & 0.1 \\
\hline$t$ & $\begin{array}{l}0,793 \\
(2,086)\end{array}$ & 0.3 & $\begin{array}{l}-4,119 \\
(2,554)\end{array}$ & -1.1 & $\begin{array}{l}1,376 \\
(1,495)\end{array}$ & 0.6 \\
\hline$t+1$ & $\begin{array}{l}-11,490^{* *} \\
(2,190)\end{array}$ & -3.8 & $\begin{array}{l}-19,858 * * \\
(3,970)\end{array}$ & -5.5 & $\begin{array}{l}-3,619 * \\
(1,616)\end{array}$ & -1.5 \\
\hline$t+2$ & $\begin{array}{l}-9,115^{* *} \\
(2,727)\end{array}$ & -3.0 & $\begin{array}{l}-20,877 * * \\
(3,402)\end{array}$ & -5.8 & $\begin{array}{l}-3,496 \\
(1,800)\end{array}$ & -1.4 \\
\hline$t+3$ & $\begin{array}{l}-11,255^{* *} \\
(2,904)\end{array}$ & -3.7 & $\begin{array}{l}-17,591 * * \\
(3,538)\end{array}$ & -4.9 & $\begin{array}{l}-3,026 \\
(2,020)\end{array}$ & -1.2 \\
\hline$t+4$ & $\begin{array}{l}-13,104^{* *} \\
(3,367)\end{array}$ & -4.4 & $\begin{array}{l}-21,667 * * \\
(4,120)\end{array}$ & -6.0 & $\begin{array}{l}-2,313 \\
(2,205)\end{array}$ & -0.9 \\
\hline
\end{tabular}


Table 11 continued

\begin{tabular}{|c|c|c|c|c|c|c|}
\hline & \multicolumn{2}{|c|}{ Manufacturing } & \multicolumn{2}{|c|}{ Tradable services } & \multicolumn{2}{|c|}{ Non-tradable services } \\
\hline & SEK & $\%$ & SEK & $\%$ & SEK & $\%$ \\
\hline \multicolumn{7}{|l|}{ Balancing indicators } \\
\hline Mean bias before & 8.3 & & 7.9 & & 12.3 & \\
\hline Mean bias after & 1.7 & & 1.8 & & 0.9 & \\
\hline Pseudo $R^{2}$ before & 0.034 & & 0.032 & & 0.053 & \\
\hline Pseudo $R^{2}$ after & 0.002 & & 0.001 & & 0.001 & \\
\hline Untreated on support & 204,747 & & 158,294 & & 388,815 & \\
\hline Treated on support & 4,861 & & 8,025 & & 6,170 & \\
\hline
\end{tabular}

The estimated parameters are based on conditional difference-in-differences (DID) propensity score matching using single nearest neighbor. For details on the specification of the propensity scores, see Sect. 4.1. Approximate standard errors in parentheses. **, * Significance at the 1 and $5 \%$ levels. Percentage effects are calculated as estimate divided by average annual earnings of displaced workers $t-3$ to $t-1$. See Table 8 for an explanation of the balancing indicators

\section{References}

Autor, D., Dorn, D., Hanson, G., \& Song, J. (2014). Trade adjustment: Worker level evidence. Quarterly Journal of Economics, 129(4), 1799-1860.

Blinder, A. (2006). Offshoring: The next industrial revolution? Foreign Affairs, 85(2), 113-128.

Borland, J., Gregg, P., Knight, G., \& Wadsworth, J. (2002). They get knocked down: Do they get up again? In P. Kuhn (Ed.), Losing work, moving on: International perspectives on worker displacement. Kalamazoo: WE Upjohn Institute for Employment Research.

Breinlich, H., \& Criscuolo, C. (2011). International trade in services: A portrait of importers and exporters. Journal of International Economics, 84(2), 188-206.

Carneiro, A., \&Portugal, P. (2006). Earnings losses of displaced workers: Evidence from a matched employer-employee data set. (IZA Discussion Paper Series No. 2289).

Couch, K., \& Placzek, D. (2010). Earnings losses of displaced workers revisited. American Economic Review, 100(1), 572-589.

Davis, S., \& von Wachter, T. (2011). Recessions and the costs of job loss. Brookings Paper on Economic Activity, 43(2(Fall)), 1-72.

Dehejia, R., \& Wahba, S. (1999). Causal effects in nonexperimental studies: Reevaluating the evaluation of training programs. Journal of the American Statistical Association, 94(448), 1053-1062.

Dehejia, R., \& Wahba, S. (2002). Propensity score matching methods for nonexperimental causal studies. Review of Economics and Statistics, 84(1), 151-161.

Ebenstein, A., Harrison, A., McMillan, M., \& Phillips, S. (2014). Estimating the impact on American workers using the Current Population Surveys. Review of Economics and Statistics, 96(4), 581-595.

Eliason, M., \& Storrie, D. (2006). Lasting or latent scars? Swedish evidence on the long-term effects of job displacement. Journal of Labor Economics, 24(4), 831-856.

Eliasson, K., Hansson, P., \& Lindvert, M. (2011). Tjänsteexporten allt viktigare för Sverige (Export of services is becoming more important in Sweden). Ekonomisk Debatt, 39(7), 28-40.

Eliasson, K., Hansson, P., \& Lindvert, M. (2012a). Jobs and exposure to international trade within the service sector in Sweden. The World Economy, 35(5), 578-608.

Eliasson, K., Hansson, P., \& Lindvert, M. (2012b). Global value chains and international competitiveness. Growth Analysis WP/PM, 2012, 23.

Fallick, B. C. (1996). A review of the recent empirical literature on displaced workers. Industrial and Labor Relations Review, 50(1), 5-16.

Francois, J., \& Hoekman, B. (2010). Services trade and policy. Journal of Economic Literature, 48(3), 642-692. 
Haller, S., Damijan, J., Kaitila, V., Kostevc, C., Maliranta, M., Milet, E., et al. (2014). Trading firms in the service sector: Comparable evidence from four EU countries. Review of World Economics/ Weltwirtschaftliches Archiv, 150(3), 471-505.

Heckman, J., Ichimura, H., Smith, J., \& Todd, P. (1998). Characterizing selection bias using experimental data. Econometrica, 66(5), 1017-1098.

Heckman, J., Ichimura, H., \& Todd, P. (1997). Matching as an econometric evaluation estimator: Evidence from evaluating a job training program. Review of Economic Studies, 64(4), 605-654.

Hijzen, A., Upward, R., \& Wright, P. (2010). The income losses of displaced workers. Journal of Human Resources, 45(1), 243-269.

Hummels, D., Jørgensen, R., Munch, J., \& Ziang, C. (2014). The wage effect of offshoring: Evidence from Danish matched worker-firm data. American Economic Review, 104(6), 1597-1629.

Huttunen, K., Møen, J., \& Salvanes, K. (2011). How destructive is creative destruction? Effects of job loss on job mobility, withdrawal and income. Journal of the European Economic Association, 9(5), 840-870.

Jacobson, L., LaLonde, R., \& Sullivan, D. (1993). Earnings losses of displaced workers. American Economic Review, 83(4), 685-709.

Jensen, B. (2011). Global trade in services. Fear, facts, and offshoring. Peterson Institute for International Economics: Washington DC.

Jensen, B., \& Kletzer, L. (2006). Tradable services: Understanding the scope and impact of service offshoring. In L. Brainard \& S. Collins (Eds.), Offshoring white-collar work-Issues and implications, Brookings Trade Forum 2005 (pp. 75-116). Washington DC: Brookings.

Jensen, B., \& Kletzer, L. (2008). "Fear" and offshoring: The scope and potential impact of imports and exports of services. Policy Brief 08-1, Peterson Institute for International Economics.

Kletzer, L. (1998). Job displacement. Journal of Economic Perspectives, 12(1), 115-136.

Kletzer, L., \& Fairlie, R. (2003). The long-term costs of job displacement for young adult workers. Industrial and Labor Relations Review, 56(4), 682-698.

Malchow-Møller, N., Munch, J., \& Skaksen, J. (2015). Services trade, goods trade and productivity: Evidence from a population of private sector firms. Review of World Economics, 151(2), 197-229.

OECD. (2013). Back to work: Re-employment, earnings and skill use after job displacement. Chapter 4 in Employment Outlook. OECD: Paris.

Rosenbaum, P., \& Rubin, D. (1983). The central role of the propensity score in observational studies for causal effects. Biometrika, 70(1), 41-55.

Rosenbaum, P., \& Rubin, D. (1985). Constructing a control group using multivariate matched sampling methods that incorporate the propensity score. The American Statistician, 39(1), 33-38.

Ruhm, C. (1991). Are workers permanently scarred by job displacements? American Economic Review, 81(1), 319-324.

Schwerdt, G. (2011). Labor turnover before plant closure: "Leaving the sinking ship" vs. "Captain throwing ballast overboard". Labour Economics, 18(1), 93-101.

Smith, J., \& Todd, P. (2005). Does matching overcome Lalonde's critique of nonexperimental estimators? Journal of Econometrics, 125(1-2), 305-353.

Stevens, A. H. (1997). Persistent effects of job displacement: The importance of multiple job losses. Journal of Labor Economics, 15(1), 165-188. 